\title{
Crystal chemical characterization of mullite-type aluminum borate compounds
}

K. Hoffmann ${ }^{\mathrm{a}, b^{*}}$, T. J. N. Hooper ${ }^{\mathrm{c}}$, H. Zhao ${ }^{\mathrm{d}}$, U. Kolb ${ }^{\mathrm{d}}$, M. M. Murshed ${ }^{\mathrm{b}, \mathrm{e}}$, M. Fischer ${ }^{\mathrm{a}, \mathrm{e}}$, H. Lührs ${ }^{\mathrm{a}, \mathrm{e}}$, G. Nénert ${ }^{\mathrm{f}}$, P. Kudějováa ${ }^{\mathrm{g}}$, A. Senyshyn ${ }^{\mathrm{g}}$, H. Schneider ${ }^{\mathrm{a}}$, J. V. Hanna ${ }^{\mathrm{c}}$, Th. M. Gesing ${ }^{\mathrm{b}, \mathrm{e}}$, R. X. Fischer ${ }^{\mathrm{a}, \mathrm{e}}$

${ }^{a}$ Kristallographie, FB05, Klagenfurter Straße / GEO, Universität Bremen, D-28359 Bremen, Germany

'Institut für Anorganische Chemie und Kristallographie, FB02, Leobener Straße / NW2, Universität Bremen, D-28359 Bremen, Germany

${ }^{\mathrm{c}}$ Department of Physics, University of Warwick, Coventry, CV4 7AL, UK

${ }^{\mathrm{d}}$ Institut für Anorganische Chemie und Analytische Chemie, Jakob-Welder-Weg 11, Johannes Gutenberg-University Mainz, D- 55128 Mainz, Germany

${ }^{\mathrm{e} M A P E X}$ Center for Materials and Processes, Bibliothekstraße 1, Universität Bremen, D-28359 Bremen, Germany

Institut Laue-Langevin, 6 Rue Jules Horowitz, 38042 Grenoble Cedex 9, France.

${ }^{\mathrm{g}}$ Heinz Maier-Leibnitz Zentrum (MLZ), Technische Universität München, Lichtenbergstr. 1, D-85748 Garching, Germany

*Corresponding author; email address: Kristin.Hoffmann@uni-bremen.de; phone: +49 (0)421 218 65172; fax: +49 (0)42121865189

${ }_{1}$ PANalytical B. V., Lelyweg 1, 7602 EA Almelo, The Netherlands 


\begin{abstract}
Al-rich aluminum borate compounds were prepared by different synthesis routes using various initial Al/B ratios, characterized by diffraction methods, spectroscopy and prompt gamma activation analysis. The ${ }^{11} \mathrm{~B}$ NMR data show a small amount of $\mathrm{BO}_{4}$ species to be present in all samples. The chemical analysis indicates a trend in the $\mathrm{Al} / \mathrm{B}$ ratio instead of a fixed composition. Both methods indicate a solid solution expressed as $\mathrm{Al}_{5-\mathrm{x}} \mathrm{B}_{1+\mathrm{x}} \mathrm{O}_{9}$ where $\mathrm{Al}$ is substituted by $\mathrm{B}$ in the range of about $1-3 \%$.

The structure of the B-rich compound $\mathrm{Al}_{4} \mathrm{~B}_{2} \mathrm{O}_{9}$ was re-investigated by electron diffraction methods, showing that structural details vary within a crystallite. In most of the domains the atoms are orderly distributed, showing no signal for the postulated channel oxygen atom O5. The absence of O5 is supported by density functional theory calculations. Other domains show a probable disordered configuration of $\mathrm{O} 5$ and $\mathrm{O} 10$, indicated by diffuse scattering along the $\mathbf{b}$ direction.
\end{abstract}

Keywords: Aluminum borate, mullite-type structure, X-ray diffraction, electron diffraction, NMR spectroscopy, PGA analysis. 


\section{Introduction}

The aluminum borates $\mathrm{Al}_{18} \mathrm{~B}_{4} \mathrm{O}_{33}\left(\mathrm{~A}_{9} \mathrm{~B}_{2}\right)$ and $\mathrm{Al}_{4} \mathrm{~B}_{2} \mathrm{O}_{9}\left(\mathrm{~A}_{2} \mathrm{~B}\right)$ belong to the family of mullitetype materials $[1,2]$, with the characteristic chains of edge-sharing octahedra, interconnected by $\mathrm{AlO}_{5-}, \mathrm{AlO}_{4-}, \mathrm{BO}_{3^{-}}$and/or $\mathrm{BO}_{4}$-groups. Because of their outstanding properties, such as low thermal expansion, high elastic modules and high tensile strength, $\mathrm{A}_{9} \mathrm{~B}_{2}$ and $\mathrm{A}_{2} \mathrm{~B}$ are of considerable research interest ([3] and references therein). $\mathrm{A}_{9} \mathrm{~B}_{2}$ is commercially available under the trade names Alborex and Alborite (Shikoku Chemical Corporation, Japan). The reinforcement of aluminum alloys by the incorporation of these Al-borate whiskers to obtain composite materials with high mechanical strength is one of their most important applications [3] (see, e.g., Tang et al. [4], Peng et al. [5] and Tao et al. [6] for further applications). However, the complex details of both crystal structures could not be solved yet. $\mathrm{A}_{9} \mathrm{~B}_{2}$ and $\mathrm{A}_{2} \mathrm{~B}$ are described to be the thermodynamically stable phases in the $\mathrm{Al}_{2} \mathrm{O}_{3}-\mathrm{B}_{2} \mathrm{O}_{3}$ system [7]. A series of $\mathrm{Al}_{6-\mathrm{x}} \mathrm{B}_{\mathrm{x}} \mathrm{O}_{9}$-compounds considered to be metastable has been described by Mazza et al. [8]. These compounds have an average structure close to mullite, crystallizing in the orthorhombic space group Pbam. A more detailed discussion about these $\mathrm{Al}_{6-\mathrm{x}} \mathrm{B}_{\mathrm{x}} \mathrm{O}_{9}$-phases is available elsewhere [9].

For the thermodynamically stable polymorph of the Al-rich aluminium borate, the exact chemical composition is an ongoing discussion. Two slightly different stoichiometries are reported: $\mathrm{Al}_{18} \mathrm{~B}_{4} \mathrm{O}_{33}\left(\mathrm{~A}_{9} \mathrm{~B}_{2}\right)$ and $\mathrm{Al}_{20} \mathrm{~B}_{4} \mathrm{O}_{36}\left(\mathrm{Al}_{5} \mathrm{BO} 9\right)$, crystallizing in the orthorhombic space group A2 1 am [10]. Crystal-structure refinements performed by Sokolova et al. [11] yielded a chemical composition of $\mathrm{Al}_{19.4} \mathrm{~B}_{4.6} \mathrm{O}_{36}$, being rounded to $\mathrm{Al}_{20} \mathrm{~B}_{4} \mathrm{O}_{36}$. Although the composition given by Sokolova et al. [11] is closer to $\mathrm{Al}_{18} \mathrm{~B}_{4} \mathrm{O}_{33}$, this compound was referenced further on as $\mathrm{Al}_{5} \mathrm{BO}_{9}(\mathrm{~A} 5 \mathrm{~B})$, as pointed out by Fischer and Schneider [2]. Based on an ordered distribution of $\mathrm{Al}$ and $\mathrm{B}, \mathrm{Al}_{20} \mathrm{~B}_{4} \mathrm{O}_{36}\left(\mathrm{~A}_{5} \mathrm{~B}\right)$ represents the idealized model. Nevertheless, a replacement of less than $2 \%$ of the $\mathrm{Al}$ atoms by $\mathrm{B}$ would yield the $\mathrm{Al}_{18} \mathrm{~B}_{4} \mathrm{O}_{33}$ composition $\left(\mathrm{Al}_{20} \mathrm{~B}_{4} \mathrm{O}_{36}\right.$ vs. $\left.\mathrm{Al}_{19.64} \mathrm{~B}_{4.36} \mathrm{O}_{36}\right)$ as described by Ihara et al. [12] and Garsche et al. [10]. Gatta 
et al. [13], Gatta et al. [14] and Fisch et al. [15] assumed a composition in a range close to $\mathrm{Al}_{5} \mathrm{BO}_{9}$. The $\mathrm{Al}-$ rich aluminum borate consists of $\mathrm{AlO}_{6^{-}}, \mathrm{AlO}_{5^{-}}$and $\mathrm{AlO}_{4^{-}}$polyhedra, $\mathrm{B}$ occurs in trigonal borate groups $\left(\mathrm{BO}_{3}\right)$ also found and confirmed in mullite-type $\mathrm{PbMBO}_{4}$ phases $(\mathrm{M}=\mathrm{Al}, \mathrm{Ga}, \mathrm{Fe}, \mathrm{Mn})$ [16-19]. A solid-solution series might be possible replacing $\mathrm{Al}$ by $\mathrm{B}$ on the $\mathrm{AlO}_{4}$ site. However, the difference of the ionic radii between $\mathrm{B}$ and $\mathrm{Al}$ would lead to a higher degree of tetrahedral distortion which might affect the thermal properties of these materials. The thermal stability of the Al-rich aluminum borate is described controversially in literature. Incongruent melting is observed at about $2223 \mathrm{~K}$ by Bauman and Moore [20] and Gielisse and Foster [7]. Scholze [21] determined an incongruent melting point at about $1713 \mathrm{~K}$, and Rymon-Lipinski et al. [22] described a decomposition into $\mathrm{Al}_{2} \mathrm{O}_{3}$ and liquid $\mathrm{B}_{2} \mathrm{O}_{3}$ at $1473 \mathrm{~K}$. For the commercial products Alborite and Alborex, the Shikoku Chemical Corporation specified the decomposition temperature as $1713 \mathrm{~K}$, describing the decomposition products as alumina and boron oxide [23].

The thermodynamically stable polymorph of the boron-rich aluminoborate $\mathrm{A}_{2} \mathrm{~B}$ is described by Fischer et al. [24] in the monoclinic space group $C 2 / m$ in an enlarged unit cell, with all lattice parameters doubled with respect to the Pbam structure and a monoclinic angle $\beta$ close to $90^{\circ}$. Its crystal structure is closely related to the boralsilite structure with Si replaced by B [24]. However, details of this complex structure concerning disorder of the oxygen atoms in the channels (O5 and $\mathrm{O} 10)$ and disorder of the interstitial cations could not be solved yet. The aim of this work is a detailed crystal-chemical characterization of the compounds $\mathrm{A}_{9} \mathrm{~B}_{2}$ and $\mathrm{A}_{2} \mathrm{~B}$, using complementary diffraction and spectroscopic methods. Structural changes of the crystal structures will be investigated as a function of the B content in the precursor phases. $\mathrm{A}_{9} \mathrm{~B}_{2}$ compounds are produced by different synthesis routes and compared to Alborite and Alborex. Moreover, the thermal stability of $\mathrm{A}_{9} \mathrm{~B}_{2}$ is investigated. 


\section{Material and methods}

\subsection{Synthesis}

Sol-gel synthesis. Series of powder samples were synthesized with a varying $\mathrm{Al}_{2} \mathrm{O}_{3} / \mathrm{B}_{2} \mathrm{O}_{3}$ ratio in the precursor phase using the nitrate decomposition method (ND) described elsewhere $[8,25,26]$. Aluminum nitrate nonahydrate $\left[\mathrm{Al}\left(\mathrm{NO}_{3}\right)_{3} \cdot 9 \mathrm{H}_{2} \mathrm{O}\right]$ and boric acid $\left[\mathrm{B}(\mathrm{OH})_{3}\right]$ were mixed and dissolved in $10 \mathrm{wt} \%$ glycerol [1,2,3-propanetriol]. The reaction of glycerol and boric acid at room temperature (RT) yields the formation of ester complexes, thus reducing the volatilization of boron [8]. $\mathrm{A}_{9} \mathrm{~B}_{2} / \mathrm{A}_{5} \mathrm{~B}$ powder samples were prepared with an excess of $10 \mathrm{~mol} \%$ boron, allowing the formation of $\mathrm{Al}_{18} \mathrm{~B}_{4} \mathrm{O}_{33}$ and/or $\mathrm{Al}_{20} \mathrm{~B}_{4} \mathrm{O}_{36}$ despite the possible loss of boron during the synthesis. Using covered platinum crucibles, $A_{2} B$ and $A_{9} B_{2} / A_{5} B$ powder samples were crystallized at $1223 \mathrm{~K}$ for $44 \mathrm{~h}$ and at $1373 \mathrm{~K}$ for $5 \mathrm{~h}$, respectively. All samples were quenched from reaction conditions to room temperature. The neutron diffraction samples (A5 and B16) were synthesized using 99 atom\% ${ }^{11} \mathrm{~B}$ raw materials in order to account for the very high absorption cross section of the isotope ${ }^{10} \mathrm{~B}$. The sample $\mathrm{A}_{2} \mathrm{~B}$ (A5) was finally heated at $1023 \mathrm{~K}$ for one hour, followed by a three days heating period at $1223 \mathrm{~K}$. The $\mathrm{A}_{9} \mathrm{~B}_{2} / \mathrm{A}_{5} \mathrm{~B}$ sample (B16) was prepared from a single-phase gel consisting of aluminum nitrate nonahydrate and boric acid, following the procedure described by Griesser et al. [27] but using glycerol instead of ethanol, the final synthesis step was performed at $1473 \mathrm{~K}$ for $5 \mathrm{~h}$.

Solid-state reaction. Series of $\mathrm{A}_{9} \mathrm{~B}_{2} / \mathrm{A}_{5} \mathrm{~B}$ powder samples were synthesized using a solidstate reaction (S) described in [15]. Aluminum oxide $\left[\alpha-\mathrm{Al}_{2} \mathrm{O}_{3}\right]$ and boron oxide $\left[\mathrm{B}_{2} \mathrm{O}_{3}\right]$ were mixed in the corresponding ratios, again using an excess of 10 mol\% boron. Carefully grained and pressed as a pellet they were crystallized at $1473 \mathrm{~K}$ for $10 \mathrm{~h}$ in covered corundum crucibles, and slowly cooled to room temperature.

Solid-state and sol-gel-samples were washed with hot deionized $\mathrm{H}_{2} \mathrm{O}$ to remove possible impurities of boron oxide. The experimental conditions used for sample characterization are given in Tables 1 and 2. Chemical compositions and composition ratios given in this work 
always refer to the initial chemical composition used in the synthesis. Due to a partial loss of $\mathrm{B}$ during the synthesis the actual composition of the $\mathrm{AB}$ phases can be different.

Table 1. Initial gel compositions of samples of the $\mathrm{A}_{2} \mathrm{~B}$ series.

\begin{tabular}{cccccc}
\hline Exp. & $\mathrm{Al}_{2} \mathrm{O}_{3} / \mathrm{wt} \%$ & $\mathrm{~B}_{2} \mathrm{O}_{3} / \mathrm{wt} \%$ & Method & Temp. /K & Time $/ \mathrm{h}$ \\
\hline $\mathrm{A} 1$ & 70 & 30 & $\mathrm{ND}$ & 1223 & 44 \\
$\mathrm{~A} 2$ & 65 & 35 & $\mathrm{ND}$ & 1223 & 44 \\
$\mathrm{~A} 3$ & 60 & 40 & $\mathrm{ND}$ & 1223 & 44 \\
$\mathrm{~A} 4$ & 35 & 65 & $\mathrm{ND}$ & 1223 & 44 \\
$\mathrm{~A} 5$ & 31 & $69\left({ }^{11} \mathrm{~B}\right)$ & $\mathrm{ND}$ & 1223 & 72 \\
\hline \multicolumn{5}{l}{ ND: nitrate decomposition method }
\end{tabular}

Table 2. Initial chemical compositions of samples of the $A_{9} B_{2} / A_{5} B$ series.

\begin{tabular}{ccccc}
\hline Exp. & $\mathrm{Al}_{2} \mathrm{O}_{3} / \mathrm{B}_{2} \mathrm{O}_{3}$ & Method & Temp. /K & Time $/ \mathrm{h}$ \\
\hline B6 & $5.0: 1.1$ & $\mathrm{ND}$ & 1373 & 5 \\
B7 & $4.5: 1.1$ & $\mathrm{ND}$ & 1373 & 5 \\
B8 & $3.0: 1.1$ & $\mathrm{ND}$ & 1373 & 5 \\
B9 & $1.5: 1.1$ & $\mathrm{ND}$ & 1373 & 5 \\
$\mathrm{~B} 10$ & $1.0: 1.1$ & $\mathrm{ND}$ & 1373 & 5 \\
$\mathrm{~B} 11$ & $5.0: 1.1$ & $\mathrm{~S}$ & 1473 & 10 \\
$\mathrm{~B} 12$ & $4.5: 1.1$ & $\mathrm{~S}$ & 1473 & 10 \\
$\mathrm{~B} 13$ & $3.0: 1.1$ & $\mathrm{~S}$ & 1473 & 10 \\
$\mathrm{~B} 14$ & $1.5: 1.1$ & $\mathrm{~S}$ & 1473 & 10 \\
$\mathrm{~B} 15$ & $1.0: 1.1$ & $\mathrm{~S}$ & 1473 & 10 \\
B16 & $4.5: 1.0\left({ }^{11} \mathrm{~B}\right)$ & $\mathrm{ND}$ & 1473 & 5 \\
\hline
\end{tabular}

ND: nitrate decomposition method; S: solid-state reaction

\subsection{Diffraction}

\section{$X$-ray powder diffraction}

X-ray powder-diffraction data were collected on a Philips X'Pert diffractometer using $\mathrm{CuK} \alpha_{1,2}$ radiation and Bragg-Brentano geometry. The instrument is equipped with a $14^{\circ}$ divergence slit, $\mathrm{a}^{1 / 2^{\circ}}$ anti-scatter slit, a soller slit $(0,04 \mathrm{rad})$ and a masc $(10 \mathrm{~mm})$ in the primary beam, as well as a soller slit (0.04 rad), a Ni-filter and a X'Celerator detector system in the secondary beam. Data were collected from $3^{\circ}-120^{\circ} 2 \theta$ (or $5^{\circ}-130^{\circ} 2 \theta$ ) with a stepsize of 
$0.0167^{\circ} 2 \theta / \mathrm{step}$ and a measuring time of $50 \mathrm{~s}$ per step, using tube settings of $45 \mathrm{kV}$ and $40 \mathrm{~mA}$.

Powder X-ray diffraction data for small amounts of samples (samples of $A_{9} B_{2} / A_{5} B$ series, investigated by thermal analysis) were collected using glass capillaries of $0.3 \mathrm{~mm}$ in diameter on a Bruker D8 diffractometer with Debye-Scherrer geometry. Monochromatic CuK $\alpha_{1}$ radiation $(\lambda=154.0598 \mathrm{pm})$ is provided by a Ge-monochromator of Johansson type (Vario 1). The instrument is equipped with an antiscatter slit $(0.1 \mathrm{~mm})$ and a soller slit $\left(4^{\circ}\right)$ in the primary beam, as well as a soller slit $\left(2.5^{\circ}\right)$, an iris aperture $(6.42 \mathrm{~mm})$ and a position sensitive detector (LynxEye) in the secondary beam. Data were collected in the range from $4^{\circ}-$ $120^{\circ} 2 \theta$, with a stepsize of $0.01976^{\circ} 2 \theta /$ step and a measuring time per step of $1 \mathrm{~s}$ with tube settings of $40 \mathrm{kV}$ and $40 \mathrm{~mA}$.

\section{Neutron powder diffraction}

Neutron powder-diffraction (NPD) data were collected for the $A_{9} B_{2} / A_{5} B$ sample at room temperature on powder diffractometer SPODI@FRM-II [28] in the high-resolution mode. A collimated beam of neutrons $(\lambda=154.838(2) \mathrm{pm})$ was provided by a $\mathrm{Ge}(551)$-monochromator with a take-off angle of $155^{\circ}$. Data were refined in the range from $5^{\circ}-150^{\circ} 2 \theta$, with a stepsize of $0.05^{\circ} 2 \theta /$ step.

Neutron powder-diffraction data for the $\mathrm{A}_{2} \mathrm{~B}$ sample were collected at room temperature at the Institut Laue Langevin. The measurements were carried out with a wavelength of $\lambda=159.21(2) \mathrm{pm}$ corresponding to the (335) Bragg reflexion of a germanium monochromator. The neutron detection is performed with ${ }^{3} \mathrm{He}$ counting tubes spaced at $1.25^{\circ}$ intervals. The data were refined in the range from $10^{\circ}-140^{\circ} 2 \theta$. A complete diffraction pattern is obtained after about 25 steps of $0.05^{\circ}$ in $2 \theta$.

\section{Rietveld refinements}

Rietveld refinements based on the X-ray and neutron powder-diffraction data were carried out for all crystalline samples using the "DiffracPlus Topas 4.2" (Bruker AXS GmbH, Karlsruhe, 
Germany) software. Impurities of $\mathrm{Al}_{2} \mathrm{O}_{3}$ were quantified if present. The lattice parameters of all samples were refined by a Pawley fit. The fundamental parameters were obtained from the refinement of $\mathrm{a} \mathrm{LaB}_{6}$ standard sample and fixed for all subsequent structure refinements. For Rietveld refinements of combined neutron and X-ray diffraction data the neutron wavelength was refined while the X-ray wavelength was fixed and the lattice parameters were refined simultaneously but constrained to be equal for both data sets. Difference Fourier calculations are based on refinements using the BRASS [29] software.

\section{Electron Diffraction}

Scanning transmission electron microscopy (STEM) and electron-diffraction measurements were carried out using a TECNAI F30 S-TWIN transmission electron microscope equipped with a field emission gun and operating at $300 \mathrm{kV}$. STEM images were collected by a FISCHIONE high angular-annular dark field (HDAAF) detector. Three dimensional nano electron-diffraction data (C2 aperture $10 \mu \mathrm{m}$, beam diameter $75 \mathrm{~nm})$ were acquired with a $4 \mathrm{k}$ Gatan CCD camera (Gatan, Pleasanton, USA) using an automated diffraction tomography (ADT) module [30] at room temperature. ADT data from single crystals were collected with a FISCHIONE tomography holder.

\subsection{Spectroscopy}

\section{MAS NMR Spectroscopy}

The ${ }^{11} \mathrm{~B}$ MAS NMR measurements were undertaken at $14.1 \mathrm{~T}$ using a Varian-600 spectrometer operating at the ${ }^{11} \mathrm{~B}$ Larmor frequency of $192.50 \mathrm{MHz}$. All ${ }^{11} \mathrm{~B}$ MAS NMR data were acquired using a Varian 4mm HX MAS probe which enabled a MAS frequency of 12 $\mathrm{kHz}$ throughout. Each reported measurement employed a 'selective' $\pi / 2$ pulse time of $5 \mu \mathrm{s}$, inferred from a 'non-selective' $\pi / 2$ pulse time of $10 \mu$ s measured on $\mathrm{NaBH}_{4}(\mathrm{~s})$, with a recycle delay of $20 \mathrm{~s}$. The quantitative nature of these measurements was tested on selected samples against experiments utilizing smaller flip angles (with the same radio frequency power levels) 
that satisfied the uniform excitation condition for quadrupolar nuclei $[31,32]$ where $(I+1 / 2)$ $\omega_{\mathrm{rf}} t_{\mathrm{p}} \leq \pi / 6$. In this case, a 'selective' (solid) $\pi / 9$ pulse time of $1.1 \mu$ s with a recycle delay of 20 $\mathrm{S}$ was used to ensure that the relative ratio between the $\mathrm{BO}_{3}$ and $\mathrm{BO}_{4}$ species remained unchanged, although a much longer acquisition time of $>24 \mathrm{~h}$ for each measurement was necessary to achieve sufficient signal/noise for this purpose. All ${ }^{11} \mathrm{~B}$ chemical shifts were referenced to $\mathrm{BF}_{3} . \mathrm{Et}_{2} \mathrm{O}\left(\delta_{\text {iso }}=0.0 \mathrm{ppm}\right)$ via a secondary solid $\mathrm{NaBH}_{4}$ reference $\left(\delta_{\text {iso }}=-42.06\right.$ ppm), and each ${ }^{11} \mathrm{~B}$ MAS NMR spectrum was simulated using the DMFit program to elucidate the relative proportions of the $\mathrm{BO}_{3}$ and $\mathrm{BO}_{4}$ species [33].

The ${ }^{27} \mathrm{Al}$ MAS NMR measurements were undertaken at $14.1 \mathrm{~T}$ and $9.40 \mathrm{~T}$ using a Bruker Avance II+-600 spectrometer operating at the ${ }^{27} \mathrm{Al}$ Larmor frequency of $156.34 \mathrm{MHz}$ and a Bruker Avance 400 spectrometer operating at the ${ }^{27} \mathrm{Al}$ Larmor frequency of $104.23 \mathrm{MHz}$, respectively. All ${ }^{27} \mathrm{Al}$ MAS NMR data were acquired using a Bruker 3.2mm HX MAS probe which enabled a MAS frequency of $20 \mathrm{kHz}$ throughout. The $14.1 \mathrm{~T}{ }^{27} \mathrm{Al}$ MAS data were acquired using a single pulse experiment which employed a 'selective' $0.80 \mu$ s excitation pulse corresponding to a $\pi / 6$ flip angle, inferred from the 'non-selective' $\pi / 2$ pulse time of 7.5 $\mu$ s measured on the $\mathrm{AlO}_{6}$ resonance of $\mathrm{YAG}(\mathrm{s})$, and a recycle delay of $2 \mathrm{~s}$. The corresponding 9.40 $\mathrm{T}^{27} \mathrm{Al}$ MAS data were acquired using the same pulse time calibration on the $\mathrm{AlO}_{6}$ $\mathrm{YAG}_{(\mathrm{s})}$ resonance, with the single pulse experiments employing a slightly longer $1 \mu \mathrm{s}$ 'selective' excitation pulse and a recycle delay of $10 \mathrm{~s}$. These pulse conditions at both $B_{0}$ fields ensured a 1:1 intensity ratio in the $\mathrm{AlO}_{4}$ and $\mathrm{AlO}_{6}$ species of the YAG spectrum. The 14.1 T 2D ${ }^{27} \mathrm{Al}$ MQMAS NMR data were acquired using a Z-filtered 3QMAS pulse sequence with a $3.5 \mu$ s excitation pulse, a $1.5 \mu$ s conversion pulse and a $17.0 \mu$ s selective final pulse. These MQMAS data were processed using TOPSPIN and then sheared using the TOPSPIN AU program $x f$ shear. All ${ }^{27} \mathrm{Al}$ chemical shifts were referenced to $1 \mathrm{M} \mathrm{Al}\left(\mathrm{NO}_{3}\right)_{3}(\mathrm{aq})$ $\left(\delta_{\text {iso }}=0.0 \mathrm{ppm}\right)$ via a secondary solid YAG reference $\left(\delta=0.7 \mathrm{ppm}\right.$ for the $\mathrm{AlO}_{6}$ site $)$. 


\section{Infrared Spectroscopy}

Fourier transform infrared (FTIR) spectra were collected on a Bruker Vertex 80v FTIR spectrometer. Using the standard $\mathrm{KBr}$ method for the mid-infrared (MIR) region, $1 \mathrm{mg}$ sample was homogenized with $200 \mathrm{mg} \mathrm{KBr}$, pressed into a pellet and measured relative to a $\mathrm{KBr}$ reference pellet. Data were obtained in a spectral range of $370 \mathrm{~cm}^{-1}-4000 \mathrm{~cm}^{-1}$ with a spectral resolution of $2 \mathrm{~cm}^{-1}$ and 32 scans per spectrum.

\section{Raman Spectroscopy}

Powder Raman spectra were collected on a Horiba LabRam Aramis using a laser of $532.04 \mathrm{~nm}$ wavelength. The spectra were recorded on pellets from $50 \mathrm{~cm}^{-1}$ to $1600 \mathrm{~cm}^{-1}$ with a spectral resolution of approx. $3.22 \mathrm{~cm}^{-1}$ and a grating of 1800 groves/mm. Pellets were pressed from the powder samples. The spectra were baseline corrected using the LabSpec Software, vers.5.

\subsection{Density-functional theory calculations}

In order to obtain more insights into the energetic stability of the positions of oxygen atoms O5 and O10, density-functional theory (DFT) calculations were performed for two different models of $\mathrm{A}_{2} \mathrm{~B}$. In the first model, the oxygen atom $\mathrm{O} 5$ was removed from the structure whereas the occupancy of $\mathrm{O} 10$ was increased to 1 to reach the correct stoichiometry (this model retains $C 2 / m$ symmetry). In the second model, the symmetry was reduced to $C m$, and half of the $\mathrm{O} 5$ and $\mathrm{O} 10$ atoms were removed.

The DFT calculations used the CASTEP code, which employs a combination of plane waves and pseudopotentials [34]. On-the-fly generated ultrasoft pseudopotentials were used to represent the core electrons, and the energy cutoff was set to $700 \mathrm{eV}$. The calculations employed the PBEsol functional, which was optimized for the treatment of solids [35]. A $1 \times 2 \times 1$ mesh of $k$-points was used to sample the first Brillouin zone. While all atomic 
coordinates were relaxed in the DFT calculations, the lattice parameters were fixed to the experimental values [24].

\subsection{Thermal analyses}

Powder samples of $A_{9} B_{2} / A_{5} B$ series were investigated by differential thermal analysis (DTA), on a Netzsch 449 F3 Jupiter STA, combining the signals of differential scanning-calorimetry (DSC) and thermal gravimetric analysis (TG). Different types of measurements were performed to investigate the stability range of selected samples and of the commercial products Alborite and Alborex. In the first case, samples were studied up to $1773 \mathrm{~K}$ (heating rate: $5 \mathrm{~K} / \mathrm{min}$; cooling rate: $30 \mathrm{~K} / \mathrm{min}$ ), in the second case, samples where heated up to $1673 \mathrm{~K}$, holding this temperature for $5 \mathrm{~h}$ (heating rate: $20 \mathrm{~K} / \mathrm{min}$; cooling rate: $30 \mathrm{~K} / \mathrm{min}$ ). All experiments were performed using uncovered crucibles and dry synthetic air atmosphere with a controlled gas flow $(50 \mathrm{ml} / \mathrm{min})$. Proteus Netzsch software [36] was used for data evaluation.

\subsection{Prompt gamma activation analysis}

Prompt gamma activation analysis (PGAA) was performed on selected samples of $\mathrm{A}_{9} \mathrm{~B}_{2} / \mathrm{A}_{5} \mathrm{~B}$ series and of the commercial products Alborite and Alborex to determine the exact Al/B ratio. Since boron is known to be volatile, volatilization of an unknown amount of boron during the synthesis is likely. A $15 \mathrm{~mm}$ lead attenuator and a special instrument configuration were used. Additional efficiency measurements were performed for these boron containing samples as discussed in [37]. Details of the PGAA system are described in [38, 39]. 


\section{Results and Discussion}

\subsection{Crystal-chemical characterization of $\mathrm{Al}_{20-x} B_{4+x} \mathrm{O}_{36}$}

\section{X-ray and Neutron powder diffraction}

Based on X-ray diffraction patterns, the products of the different synthesis routes and different initial $\mathrm{Al} / \mathrm{B}$ ratios are compared. Pure and well crystallized $\mathrm{A}_{9} \mathrm{~B}_{2} / \mathrm{A}_{5} \mathrm{~B}$ phases are observed in solid state derived samples B13-B15 which belong to the high $\mathrm{B}_{2} \mathrm{O}_{3}$ region (Tab. 2). In the high $\mathrm{Al}_{2} \mathrm{O}_{3}$ region (B11, B12) close to the $\mathrm{A}_{9} \mathrm{~B}_{2}$ phase boundary [7] additional diffraction peaks occur, which can be assigned to $\alpha$-alumina most probably resulting from a loss of boron. For comparable samples with the same initial composition synthesized using the nitrate decomposition method (B6, B7), formation of alumina was not observed. This supports the argument of Mazza et al. [8] and our finding [9] pointing out that the volatilization of boron is reduced due to the reaction of glycerine and boric acid at RT. Even for the sample $\mathrm{B} 6(\mathrm{Al} / \mathrm{B}>4.5)$ the formation of $\mathrm{Al}_{2} \mathrm{O}_{3}$ is not observed. Therefore, the diffraction data suggest that the phase boundary might not be defined to the stoichiometric composition of $\mathrm{Al}_{18} \mathrm{~B}_{4} \mathrm{O}_{33}$ as published by Gielisse and Foster [7]. In the high $\mathrm{B}_{2} \mathrm{O}_{3}$ region, small amounts of the stable $\mathrm{A}_{2} \mathrm{~B}$ polymorph are observed as additional phase for samples $\mathrm{B} 8$ and B9 synthesized by the nitrate decomposition method. The reason might be that the synthesis temperature of the samples B5 - $9(1373 \mathrm{~K})$ is very close to the decomposition temperature of $\mathrm{A}_{2} \mathrm{~B}[21,25]$. Already in our previous work [9], it turned out that even small differences in temperature or homogeneity could have an influence in the synthesis products of aluminum borate compounds. The presence of boric acid derived from the hydration of previously amorphous B-O compounds was excluded by repeated collection of diffraction patterns for selected samples after two years.

The lattice parameters and the average crystallite size were refined using a Pawley fit. The samples B6 and B7 show various observed diffraction peaks are broadened or narrowed compared to the calculated profiles. This behavior varies within hkl series of different order 
and is obvious for the (111) reflection which is observed much more broadened than calculated and, in comparison, the (222) reflection is observed narrower than calculated. It is likely that theses effects are caused by disorder effects in the crystal structure supported by the results of ${ }^{27}$ MAS NMR data (see part spectroscopy). A trend of an increasing crystallite size is observed for increasing initial boron content. Using the solid-state reaction, the crystallite size increases compared to samples synthesized by the nitrate decomposition method. A possible explanation is the higher synthesis temperature and longer heating period. No such trend is observed for lattice parameters and cell volume (Tab. 3).

Table 3. Refined lattice parameters and crystallite sizes for the $A_{9} B_{2} / A_{5} B$ series.

\begin{tabular}{|c|c|c|c|c|c|c|c|c|}
\hline \multirow[t]{2}{*}{ Exp. } & \multirow{2}{*}{$\begin{array}{c}\text { Initial } \\
\mathrm{Al}_{2} \mathrm{O}_{3} / \mathrm{B}_{2} \mathrm{O}_{3}\end{array}$} & \multirow[t]{2}{*}{ Method } & \multicolumn{3}{|c|}{ Lattice parameter } & \multirow{2}{*}{$\begin{array}{c}\text { Cell } \\
\text { volume } \\
V / 10^{6} \mathrm{pm}^{3}\end{array}$} & \multirow{2}{*}{$\begin{array}{c}\text { Average } \\
\text { crystallite } \\
\text { size } \\
\mathrm{L}_{\mathrm{Vol}}(\mathrm{IB}) \\
\text { /nm }\end{array}$} & \multirow{2}{*}{$\begin{array}{c}\text { Phase } \\
\text { content } \\
\mathrm{Al}_{2} \mathrm{O}_{3} \\
/ \mathrm{wt} \%\end{array}$} \\
\hline & & & $a / \mathrm{pm}$ & $b / \mathrm{pm}$ & $c / \mathrm{pm}$ & & & \\
\hline B6 & $5.0: 1.1$ & ND & $768.7(1)$ & $1504.2(3)$ & $566.94(6)$ & $655.52(15)$ & $25.4(3)$ & 0 \\
\hline B7 & $4.5: 1.1$ & ND & $768.94(8)$ & $1503.7(2)$ & $566.94(5)$ & $655.51(12)$ & $26.3(3)$ & 0 \\
\hline $\mathrm{B} 8$ & $3.0: 1.1$ & ND & $769.13(7)$ & $1500.1(1)$ & $565.74(3)$ & $652.75(9)$ & $38.2(3)$ & 0 \\
\hline B9 & $1.5: 1.1$ & ND & $768.85(3)$ & $1500.76(6)$ & $566.45(2)$ & $653.60(4)$ & $88(1)$ & 0 \\
\hline B10 & 1.0:1.1 & ND & $768.87(2)$ & $1500.68(5)$ & $566.57(1)$ & $653.72(3)$ & $130(2)$ & 0 \\
\hline B11 & $5.0: 1.1$ & $S$ & $769.34(2)$ & $1501.35(4)$ & $566.54(1)$ & $654.39(3)$ & $152(2)$ & 6 \\
\hline B12 & $4.5: 1.1$ & S & $769.32(2)$ & $1501.55(4)$ & $566.518(9)$ & $654.43(2)$ & $169(2)$ & 3 \\
\hline B13 & 3.0:1.1 & S & $769.23(2)$ & $1501.23(4)$ & $566.62(1)$ & $654.33(2)$ & $168(2)$ & 0 \\
\hline B14 & $1.5: 1.1$ & S & $769.20(1)$ & $1501.03(3)$ & $566.773(9)$ & $654.39(2)$ & $184(2)$ & 0 \\
\hline B15 & $1.0: 1.1$ & S & $769.21(1)$ & $1501.04(3)$ & $566.768(9)$ & $654.40(2)$ & 211(3) & 0 \\
\hline $\mathrm{B}^{*} 6^{*}$ & $4.5: 1.0$ & ND & $769.42(1)$ & $1501.87(3)$ & $566.429(8)$ & $654.55(2)$ & $128(1)$ & 0 \\
\hline Alborite & unknown & & $769.41(3)$ & $1501.95(7)$ & $567.06(2)$ & $655.30(5)$ & $54.5(4)$ & 0 \\
\hline Alborex & unknown & & $769.08(2)$ & $1500.60(4)$ & $567.34(2)$ & $654.76(4)$ & $209(3)$ & 0 \\
\hline
\end{tabular}

Alborex is described having needle-like crystals, thus causing texture effects in (001)direction. SEM images of Alborite and Alborex are shown in Figure 1 confirming Alborex to crystallize as whiskers, whereas Alborite occurs in small needles arranged in the form of spherical aggregates. 
Rietveld refinements were performed on sample $\mathrm{B} 16$ enriched with ${ }^{11} \mathrm{~B}$, combining the data of X-ray and neutron-diffraction experiments. The refined atomic parameters using the original model of Garsche et al. [10] with all positions fully occupied are listed in Table 4. No preferred orientation effect in (001) is observed for the samples synthesized by us. A restriction of a minimum value of $0.2 * 10^{4} \mathrm{pm}^{2}$ had to be used for the isotropic displacement parameter $\mathrm{U}_{\mathrm{eq}}$ for boron in order to prevent the refinement to a negative value. The Rietveld plots of both X-ray and neutron diffraction data are shown in Figure 2.
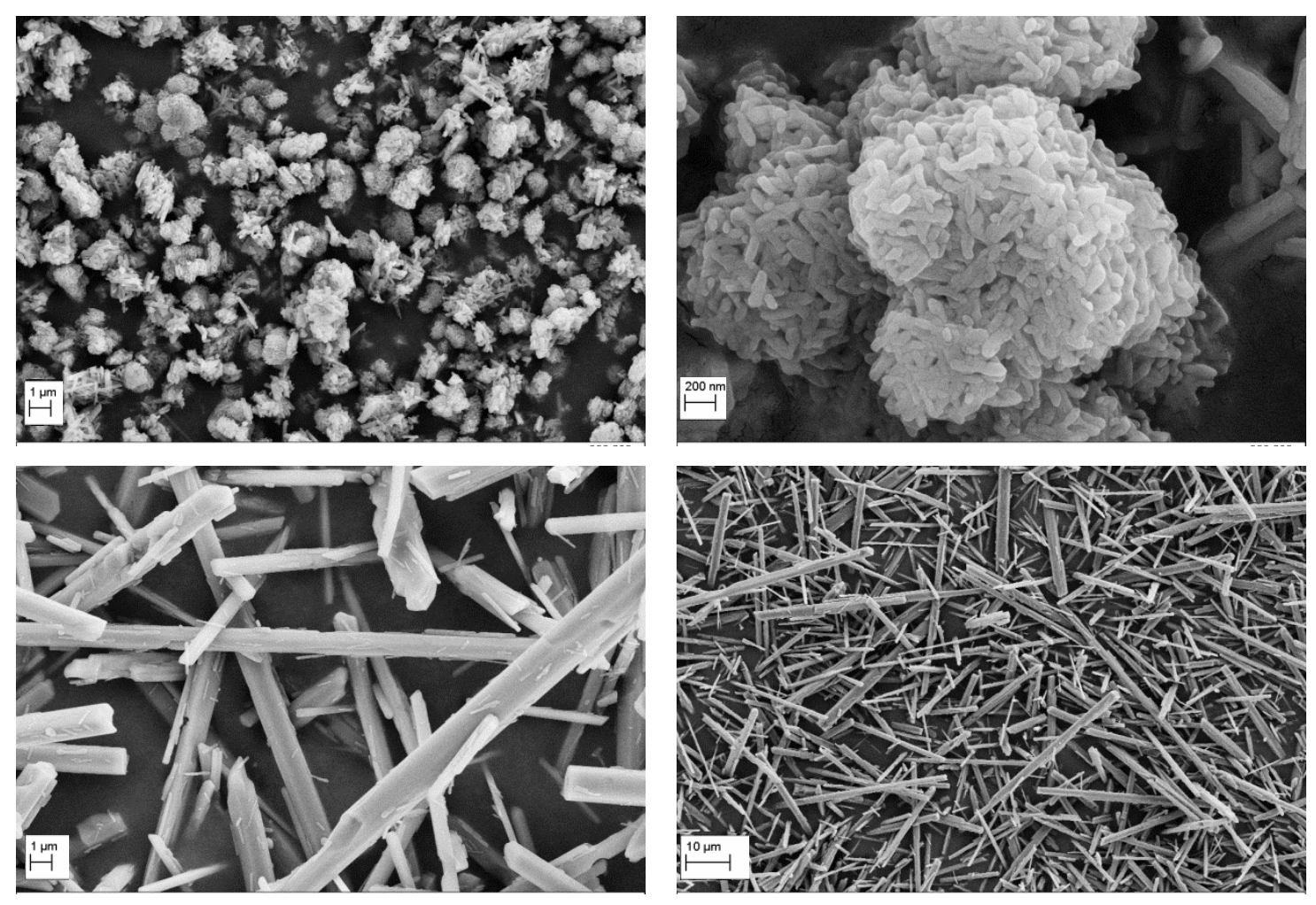

Figure 1. SEM images obtained for Alborite (top) and Alborex (bottom), carried out on a Jeol JSM-6510 scanning electron microscope [Jeol (Germany) GmbH, Echingen, Germany] using an excitation voltage of $10 \mathrm{kV}$. 
Table 4. Crystallographic data obtained from combined refinements of X-ray and neutron diffraction data using the model of Garsche et al. [10].

\begin{tabular}{cccccccc}
\hline Atom & multiplicity & Wyckoff & $x$ & $y$ & $z$ & Occu. & $B_{i s o} / 10^{4} \mathrm{pm}^{2}$ \\
\hline $\mathrm{B} 1$ & 4 & $a$ & $0.7194(5)$ & $0.0155(2)$ & 0 & 1 & $0.2^{*}$ \\
$\mathrm{~A} 11$ & 8 & $b$ & $1 / 2$ & $0.3832(1)$ & $0.2479(4)$ & 1 & $0.14(3)$ \\
$\mathrm{A} 12$ & 4 & $a$ & $0.6881(4)$ & $0.2445(2)$ & $1 / 2$ & 1 & $0.23(5)$ \\
$\mathrm{A} 13$ & 4 & $a$ & $0.6810(5)$ & $0.0549(2)$ & $1 / 2$ & 1 & $0.42(5)$ \\
$\mathrm{A} 14$ & 4 & $a$ & $0.8323(5)$ & $0.2974(2)$ & 0 & 1 & $0.15(5)$ \\
O1 & 8 & $b$ & $0.7846(4)$ & $0.0479(1)$ & $0.2117(3)$ & 1 & $0.33(3)$ \\
O2 & 8 & $b$ & $0.7012(4)$ & $0.3103(1)$ & $0.2426(3)$ & 1 & $0.22(3)$ \\
O3 & 4 & $a$ & $0.5369(4)$ & $0.1480(2)$ & $1 / 2$ & 1 & $0.31(4)$ \\
O4 & 4 & $a$ & $0.9351(5)$ & $0.1923(2)$ & 0 & 1 & $0.21(4)$ \\
O5 & 4 & $a$ & $0.8704(4)$ & $0.1703(2)$ & $1 / 2$ & 1 & $0.21(4)$ \\
O6 & 4 & $a$ & $0.5729(4)$ & $0.4548(2)$ & 0 & 1 & $0.12(4)$ \\
O7 & 4 & $a$ & $0.5916(4)$ & $0.4529(2)$ & $1 / 2$ & 1 & $0.43(4)$ \\
\hline
\end{tabular}

* $B_{\text {iso }}$ for $\mathrm{B} 1$ restricted to a minimum of 0.2
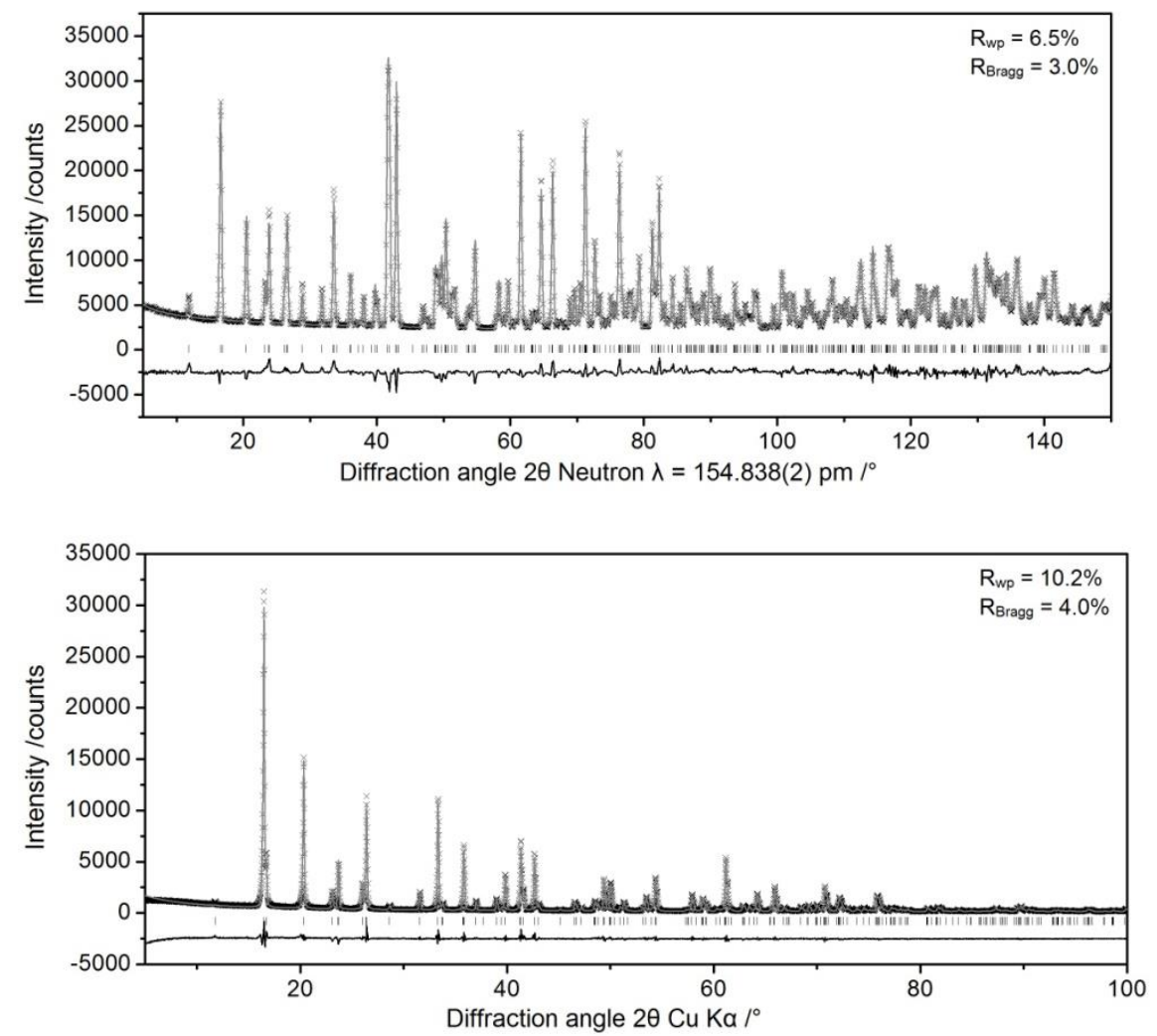

Figure 2. Rietveld plots of neutron powder-diffraction data (top) and X-ray powderdiffraction room-temperature data (bottom) refinement results (sample B16) using the original crystal-structure model of Garsche et al. [10]. Observed intensities (black crosses), calculated intensities (gray curve), positions of reflections (tick marks) and the difference curve between observed and calculated data (lower curve) are shown. 
Using the crystal-structure model of Garsche et al. [10], plausible modifications of the model were tested: In separate refinements the occupancy of each Al site was optimized. This results in full occupancy for the Al1, Al3 and Al4 site. For the Al2 site a vacancy of 3.3(6)\% was observed, while fixing the displacement factor during the refinement due to the correlation of these two values. A mixed occupancy of aluminum and boron on the $\mathrm{Al} 2$ site might be possible. However, a significant result cannot be obtained from the diffraction experiments. Fisch et al. [15] found vacancies of 2.1(4) $\%$ and 3.2(4) $\%$ on the Al2 site, using single crystals with an initial $\mathrm{Al}_{2} \mathrm{O}_{3}: \mathrm{B}_{2} \mathrm{O}_{3}$ ratio of $9: 2$ or 1:2, respectively. They determined a small amount of $\mathrm{B}$ on the $\mathrm{Al} 2$ position, coherent with their refined vacancy on the Al2 site [15].

Difference-Fourier neutron diffraction data calculations were performed. The highest maximum was found for $\mathrm{B}$ at $x=0.71, y=0.02, z=0$, corresponding to the position given in the published model [10]. No new boron position could be found.

\section{Chemical Analysis}

The Al/B ratio was calculated from the measured at $\%$ of the PGAA data (Tab. 5). None of the samples show the exact chemical composition of $\mathrm{Al}_{20} \mathrm{~B}_{4} \mathrm{O}_{36}$ or $\mathrm{Al}_{19.64} \mathrm{~B}_{4.36} \mathrm{O}_{36}$ (corresponding to $\mathrm{Al}_{18} \mathrm{~B}_{4} \mathrm{O}_{33}$ ). A decreasing $\mathrm{Al} / \mathrm{B}$ ratio is determined for all synthesized samples upon increasing initial boron content. For sample B8, an impurity of a small amount of $\mathrm{A}_{2} \mathrm{~B}$ leads to a smaller $\mathrm{Al} / \mathrm{B}$ ratio. A comparison of sample $\mathrm{B} 10$ and $\mathrm{B} 15$, both synthesized with an initial ratio of $1: 1.1(\mathrm{Al} / \mathrm{B})$, show the determined $\mathrm{Al} / \mathrm{B}$ ratio to be smaller for the samples synthesized by the solid-state reaction as this route combined with a higher and longer heating period causes a higher loss of boron.

However, although the calculated values for the samples in both series are equal within the estimated errors, the differences in the chemical compositions indicate a solid-solution series within narrow limits. Standardized to a unit-cell content of $\mathrm{Al}_{5-\mathrm{x}} \mathrm{B}_{1+\mathrm{x}} \mathrm{O}_{9}, x$ is determined as 
$0.07(11)<x<0.14(11)$ for the synthesized samples compared with the narrow range of $0.021(6)<x<0.038(6)$ for the composition of $\mathrm{Al}_{5-\mathrm{x}} \mathrm{B}_{1+\mathrm{x}} \mathrm{O}_{9}$ reported by Fisch et al. [15].

Table 5. Calculated Al/B ratio from PGAA for the commercial products and synthesized samples differing in synthesis routes and initial boron content; the determined chemical formula is standardized to a unit-cell content of $\mathrm{Al}_{20} \mathrm{~B}_{4} \mathrm{O}_{36}$ and, for a better comparison to literature data, to $\mathrm{Al}_{5} \mathrm{BO}_{9}$.

\begin{tabular}{cccccccc}
\hline Exp. & Initial & Method & \multicolumn{2}{c}{ PGAA / mol\% } & calculated & \multicolumn{2}{c}{ calculated chem. formula } \\
& $\mathrm{Al}_{2} \mathrm{O}_{3} / \mathrm{B}_{2} \mathrm{O}_{3}$ & & $\mathrm{Al}$ & $\mathrm{B}$ & $\mathrm{Al} / \mathrm{B}$ & $\mathrm{Al}_{20-\mathrm{x}} \mathrm{B}_{4+\mathrm{x}} \mathrm{O}_{36}$ & $\mathrm{Al}_{5-\mathrm{x}} \mathrm{B}_{1+\mathrm{x}} \mathrm{O}_{9}$ \\
\hline $\mathrm{B} 6$ & $5.0: 1.1$ & $\mathrm{ND}$ & $82.2(3)$ & $17.8(16)$ & $4.63(42)$ & $\mathrm{Al}_{19.73(07)} \mathrm{B}_{4.27(38)} \mathrm{O}_{36}$ & $\mathrm{Al}_{4.93(2)} \mathrm{B}_{1.07(10)} \mathrm{O}_{9}$ \\
$\mathrm{~B} 7$ & $4.5: 1.1$ & $\mathrm{ND}$ & $82.2(3)$ & $17.9(16)$ & $4.60(41)$ & $\mathrm{Al}_{19.72(07)} \mathrm{B}_{4.28(38)} \mathrm{O}_{36}$ & $\mathrm{Al}_{4.93(2)} \mathrm{B}_{1.07(10)} \mathrm{O}_{9}$ \\
$\mathrm{~B} 8$ & $3.0: 1.1$ & $\mathrm{ND}$ & $79.1(4)$ & $20.9(15)$ & $3.79(43)$ & $\mathrm{Al}_{19.00(10)} \mathrm{B}_{5.00(36)} \mathrm{O}_{36}$ & $\mathrm{Al}_{4.75(2)} \mathrm{B}_{1.25(10)} \mathrm{O}_{9}$ \\
$\mathrm{~B} 10$ & $1.0: 1.1$ & $\mathrm{ND}$ & $81.1(4)$ & $18.9(18)$ & $4.28(41)$ & $\mathrm{Al}_{19.46(10)} \mathrm{B}_{4.54(43)} \mathrm{O}_{36}$ & $\mathrm{Al}_{4.86(2)} \mathrm{B}_{1.14(11)} \mathrm{O}_{9}$ \\
$\mathrm{~B} 13$ & $3.0: 1.1$ & $\mathrm{~S}$ & $81.8(4)$ & $18.2(16)$ & $4.48(39)$ & $\mathrm{Al}_{19.62(10)} \mathrm{B}_{4.37(38)} \mathrm{O}_{36}$ & $\mathrm{Al}_{4.91(2)} \mathrm{B}_{1.09(1)} \mathrm{O}_{9}$ \\
$\mathrm{~B} 14$ & $1.5: 1.1$ & $\mathrm{~S}$ & $81.7(4)$ & $18.3(16)$ & $4.47(39)$ & $\mathrm{Al}_{19.61(10)} \mathrm{B}_{4.39(38)} \mathrm{O}_{36}$ & $\mathrm{Al}_{4.90(2)} \mathrm{B}_{1.10(10)} \mathrm{O}_{9}$ \\
$\mathrm{~B} 15$ & $1.0: 1.1$ & $\mathrm{~S}$ & $81.6(4)$ & $18.4(16)$ & $4.43(39)$ & $\mathrm{Al}_{19.58(10)} \mathrm{B}_{4.42(38)} \mathrm{O}_{36}$ & $\mathrm{Al}_{4.89(2)} \mathrm{B}_{1.11(10)} \mathrm{O}_{9}$ \\
& & & & & & & \\
Alborite & unknown & & $82.7(3)$ & $17.3(16)$ & $4.78(44)$ & $\mathrm{Al}_{19.85(7)} \mathrm{B}_{4.15(38)} \mathrm{O}_{36}$ & $\mathrm{Al}_{4.96(2)} \mathrm{B}_{1.04(10)} \mathrm{O}_{9}$ \\
Alborex & unknown & & $82.2(4)$ & $17.8(16)$ & $4.60(41)$ & $\mathrm{Al}_{19.7(1)} \mathrm{B}_{4.28(38)} \mathrm{O}_{36}$ & $\mathrm{Al}_{4.93(2)} \mathrm{B}_{1.07(10)} \mathrm{O}_{9}$ \\
\hline
\end{tabular}

ND: nitrate decomposition method; S: solid-state reaction

\section{Spectroscopy}

Solid state ${ }^{11} \mathrm{~B}$ and ${ }^{27} \mathrm{Al}$ MAS NMR data were acquired for samples of both synthesized series and for the commercial products (Fig. 3). Additional ${ }^{27} \mathrm{Al} \mathrm{MQMAS} \mathrm{measurements} \mathrm{were}$ acquired for selected samples (see Fig. 4). The summarized measured NMR parameters are shown in Tables 6 and 7. The ${ }^{11}$ B MAS NMR spectra show boron to be mainly represented by 3-fold $\left(\mathrm{BO}_{3}\right)$ coordination environments. A small amount of 1\%-3\% 4-fold coordinated boron is present in all samples independent from the synthesis route. The trigonal planar $\mathrm{BO}_{3}$ positions were fitted by a second order broadened quadrupolar resonance representing quadrupole coupling constants $\left(C_{\mathrm{Q}}\right)$ of $\sim 2.6 \mathrm{MHz}$ with a chemical shift $\left(\delta_{\text {iso }}\right)$ of $\sim 16.5 \mathrm{ppm}$ and an asymmetry parameter $\left(\eta_{\mathrm{Q}}\right)$ of $\sim 0.07-0.12$. The single or multiple $\mathrm{BO}_{4}$ positions were simulated with Gaussian line-shapes. As multiple $\mathrm{BO}_{4}$ resonances were observed for nearly all samples (Tab. 6) the NMR data may suggest that boron does not replace aluminum on a 
single $\mathrm{Al}$ site but could be placed as $\mathrm{BO}_{4}$ group at an interstitial position. A trend of an increasing site occupancy of 4-coordinated $\mathrm{BO}_{4}$ is observed with increasing initial $\mathrm{B}$ content confirming the assumption of a solid solution within a narrow limit.

Table 6. ${ }^{11} \mathrm{~B}$ solid state NMR parameters obtained from simulated fits for selected samples of $\mathrm{A}_{9} \mathrm{~B}_{2} / \mathrm{A}_{5} \mathrm{~B}$ series.

\begin{tabular}{|c|c|c|c|c|c|c|c|c|c|c|}
\hline \multirow[t]{2}{*}{$\#$} & \multicolumn{2}{|c|}{$\begin{array}{c}\text { initial } \\
\text { composition } \\
\text { /wt } \%\end{array}$} & \multirow[t]{2}{*}{ Fit } & \multirow{2}{*}{$\begin{array}{c}\boldsymbol{\delta}_{\text {iso }} \\
/ \mathbf{p p m} \\
( \pm 1) \\
\end{array}$} & \multirow{2}{*}{$\begin{array}{c}C_{\mathbf{Q}} \\
/ \mathbf{M H z} \\
( \pm 0.1) \\
\end{array}$} & \multirow{2}{*}{$\begin{array}{c}\eta_{Q} \\
( \pm 0.01) \\
\end{array}$} & \multirow{2}{*}{$\begin{array}{c}\Delta \text { (width) } \\
\text { /KHz } \\
( \pm 0.05)\end{array}$} & \multirow[t]{2}{*}{ species } & \multirow{2}{*}{$\begin{array}{c}\text { integr. } \\
\text { Int } \\
1 \% \\
\end{array}$} & \multirow{2}{*}{$\begin{array}{c}\text { Species } \\
\text { Int. } \\
1 \%\end{array}$} \\
\hline & $\mathrm{Al}_{2} \mathrm{O}_{3}$ & $\mathrm{~B}_{2} \mathrm{O}_{3}$ & & & & & & & & \\
\hline & \multicolumn{2}{|c|}{ Alborite } & 1/2 QMAS & 16.5 & 2.6 & 0.09 & - & $\mathrm{BO}_{3}$ & $98 \pm 1$ & $98 \pm 1$ \\
\hline & & & Gaussian & 2.4 & - & - & 0.12 & $\mathrm{BO}_{4}$ & $1 \pm 1$ & \\
\hline & & & Gaussian & 0.2 & - & - & 0.46 & $\mathrm{BO}_{4}$ & $1 \pm 1$ & $2 \pm 1$ \\
\hline & \multicolumn{2}{|c|}{ Alborex } & 1/2 QMAS & 16.7 & 2.7 & 0.07 & - & $\mathrm{BO}_{3}$ & $98 \pm 1$ & $98 \pm 1$ \\
\hline & & & Gaussian & 2.6 & - & - & 0.14 & $\mathrm{BO}_{4}$ & $2 \pm 1$ & $2 \pm 1$ \\
\hline \multirow[t]{2}{*}{ B6 } & 82 & 18 & 1/2 QMAS & 16.5 & 2.6 & 0.12 & - & $\mathrm{BO}_{3}$ & $99 \pm 1$ & $99 \pm 1$ \\
\hline & & & Gaussian & 0.2 & - & - & 0.19 & $\mathrm{BO}_{4}$ & $1 \pm 1$ & $1 \pm 1$ \\
\hline \multirow[t]{2}{*}{ B7 } & 80.4 & 19.6 & 1/2 QMAS & 16.5 & 2.6 & 0.11 & - & $\mathrm{BO}_{3}$ & $98 \pm 1$ & $98 \pm 1$ \\
\hline & & & Gaussian & 0.7 & - & - & 0.39 & $\mathrm{BO}_{4}$ & $2 \pm 1$ & $2 \pm 1$ \\
\hline \multirow[t]{3}{*}{ B10 } & 47.6 & 52.4 & 1/2 QMAS & 16.6 & 2.6 & 0.09 & - & $\mathrm{BO}_{3}$ & $97 \pm 1$ & $97 \pm 1$ \\
\hline & & & Gaussian & 2.5 & - & - & 0.16 & $\mathrm{BO}_{4}$ & $2 \pm 1$ & \\
\hline & & & Gaussian & -0.7 & - & - & 0.29 & $\mathrm{BO}_{4}$ & $1 \pm 1$ & $3 \pm 1$ \\
\hline \multirow[t]{3}{*}{ B11 } & 82 & 18 & 1/2 QMAS & 16.3 & 2.6 & 0.09 & - & $\mathrm{BO}_{3}$ & $98 \pm 1$ & $98 \pm 1$ \\
\hline & & & Gaussian & 2.3 & - & - & 0.20 & $\mathrm{BO}_{4}$ & $1 \pm 1$ & \\
\hline & & & Gaussian & 0.3 & - & - & 0.20 & $\mathrm{BO}_{4}$ & $1 \pm 1$ & $2 \pm 1$ \\
\hline \multirow[t]{3}{*}{ B12 } & 80.4 & 19.6 & 1/2 QMAS & 16.3 & 2.6 & 0.09 & - & $\mathrm{BO}_{3}$ & $98 \pm 1$ & $98 \pm 1$ \\
\hline & & & Gaussian & 2.3 & - & - & 0.22 & $\mathrm{BO}_{4}$ & $1 \pm 1$ & $2 \pm 1$ \\
\hline & & & Gaussian & 0.0 & - & - & 0.25 & $\mathrm{BO}_{4}$ & $1 \pm 1$ & $2 \pm 1$ \\
\hline \multirow[t]{3}{*}{ B14 } & 57.7 & 42.3 & 1/2 QMAS & 16.4 & 2.6 & 0.09 & - & $\mathrm{BO}_{3}$ & $97 \pm 1$ & $97 \pm 1$ \\
\hline & & & Gaussian & 2.3 & - & - & 0.19 & $\mathrm{BO}_{4}$ & $2 \pm 1$ & \multirow{2}{*}{$3 \pm 1$} \\
\hline & & & Gaussian & -0.3 & - & - & 0.21 & $\mathrm{BO}_{4}$ & $1 \pm 1$ & \\
\hline
\end{tabular}

$\delta_{\text {iso }}=$ chemical shift, $C_{\mathrm{Q}}=$ quadrupole coupling constants, $\eta_{\mathrm{Q}}=$ asymmetry parameter 
Table 7. ${ }^{27} \mathrm{Al}$ solid state NMR parameters obtained from simulated fits for selected samples of $\mathrm{A}_{9} \mathrm{~B}_{2} / \mathrm{A}_{5} \mathrm{~B}$ series.

\begin{tabular}{|c|c|c|c|c|c|c|c|c|c|c|}
\hline \multirow[t]{12}{*}{$\#$} & \multicolumn{2}{|c|}{$\begin{array}{l}\text { initial } \\
\text { composition } \\
\text { /wt } \%\end{array}$} & \multirow[t]{2}{*}{ fit } & \multirow{2}{*}{$\begin{array}{c}\delta_{\text {iso }} \\
/ \mathbf{p p m} \\
( \pm 1) \\
\end{array}$} & \multirow{2}{*}{$\begin{array}{c}C_{\mathbf{Q}} \\
/ \mathbf{M H z} \\
( \pm 0.1) \\
\end{array}$} & \multirow{2}{*}{$\begin{array}{c}\eta_{Q} \\
( \pm 0.01) \\
\end{array}$} & \multirow{2}{*}{$\begin{array}{c}\Delta \text { (width) } \\
/ \mathbf{K H z} \\
( \pm 0.05)\end{array}$} & \multirow[t]{2}{*}{ species } & \multicolumn{2}{|c|}{$\begin{array}{l}\text { integrated intensity } \\
\qquad 1 \%\end{array}$} \\
\hline & $\mathrm{Al}_{2} \mathrm{O}_{3}$ & $\mathrm{~B}_{2} \mathrm{O}_{3}$ & & & & & & & & (without $\mathrm{Al}_{2} \mathrm{O}_{3}$ ) \\
\hline & \multicolumn{2}{|c|}{ Alborite } & 1/2 QMAS & 72 & 9.2 & 0.45 & - & $\mathrm{AlO}_{4}$ & $24 \pm 1$ & $24 \pm 1$ \\
\hline & & & 1/2 QMAS & 52 & 6.8 & 0.04 & - & $\mathrm{AlO}_{5}$ & $18 \pm 1$ & $18 \pm 1$ \\
\hline & & & 1/2 QMAS & 45 & 8.0 & 0.75 & - & $\mathrm{AlO}_{5}$ & $16 \pm 1$ & $16 \pm 1$ \\
\hline & & & Gaussian & 10 & - & - & 0.46 & $\mathrm{AlO}_{6}$ & $1 \pm 1$ & $1 \pm 1$ \\
\hline & & & 1/2 QMAS & 9 & 5.8 & 0.30 & - & $\mathrm{AlO}_{6}$ & $42 \pm 1$ & $42 \pm 1$ \\
\hline & \multicolumn{2}{|c|}{ Alborex } & 1/2 QMAS & 72 & 9.3 & 0.38 & - & $\mathrm{AlO}_{4}$ & $18 \pm 1$ & $18 \pm 1$ \\
\hline & & & 1/2 QMAS & 52 & 6.8 & 0.05 & - & $\mathrm{AlO}_{5}$ & $20 \pm 1$ & $20 \pm 1$ \\
\hline & & & 1/2 QMAS & 44 & 7.9 & 0.63 & - & $\mathrm{AlO}_{5}$ & $20 \pm 1$ & $20 \pm 1$ \\
\hline & & & Gaussian & 10 & - & - & 0.40 & $\mathrm{AlO}_{6}$ & $2 \pm 1$ & $2 \pm 1$ \\
\hline & & & 1/2 QMAS & 9 & 5.8 & 0.37 & - & $\mathrm{AlO}_{6}$ & $42 \pm 1$ & $42 \pm 1$ \\
\hline \multirow[t]{4}{*}{ B6 } & 82 & 18 & 1/2 QMAS & 73 & 9.5 & 0.45 & - & $\mathrm{AlO}_{4}$ & $30 \pm 1$ & $30 \pm 1$ \\
\hline & & & 1/2 QMAS & 52 & 6.9 & 0.06 & - & $\mathrm{AlO}_{5}$ & $14 \pm 1$ & $14 \pm 1$ \\
\hline & & & 1/2 QMAS & 47 & 8.3 & 0.80 & - & $\mathrm{AlO}_{5}$ & $12 \pm 1$ & $12 \pm 1$ \\
\hline & & & 1/2 QMAS & 9 & 5.8 & 0.06 & - & $\mathrm{AlO}_{6}$ & $44 \pm 1$ & $44 \pm 1$ \\
\hline \multirow[t]{4}{*}{ B7 } & 80.4 & 19.6 & 1/2 QMAS & 72 & 9.3 & 0.43 & - & $\mathrm{AlO}_{4}$ & $28 \pm 1$ & $28 \pm 1$ \\
\hline & & & 1/2 QMAS & 52 & 6.8 & 0.06 & - & $\mathrm{AlO}_{5}$ & $14 \pm 1$ & $14 \pm 1$ \\
\hline & & & 1/2 QMAS & 52 & 9.0 & 0.81 & - & $\mathrm{AlO}_{5}$ & $18 \pm 1$ & $18 \pm 1$ \\
\hline & & & 1/2 QMAS & 9 & 5.9 & 0.30 & - & $\mathrm{AlO}_{6}$ & $40 \pm 1$ & $40 \pm 1$ \\
\hline \multirow[t]{5}{*}{ B10 } & 47.6 & 52.4 & 1/2 QMAS & 72 & 9.2 & 0.44 & - & $\mathrm{AlO}_{4}$ & $23 \pm 1$ & $23 \pm 1$ \\
\hline & & & 1/2 QMAS & 52 & 6.8 & 0.08 & - & $\mathrm{AlO}_{5}$ & $20 \pm 1$ & $20 \pm 1$ \\
\hline & & & 1/2 QMAS & 45 & 8.0 & 0.77 & - & $\mathrm{AlO}_{5}$ & $18 \pm 1$ & $18 \pm 1$ \\
\hline & & & Gaussian & 10 & - & - & 0.20 & $\mathrm{AlO}_{6}$ & $1 \pm 1$ & $1 \pm 1$ \\
\hline & & & 1/2 QMAS & 9 & 5.8 & 0.36 & - & $\mathrm{AlO}_{6}$ & $39 \pm 1$ & $39 \pm 1$ \\
\hline \multirow[t]{5}{*}{ B11 } & 82 & 18 & 1/2 QMAS & 71 & 9.1 & 0.45 & - & $\mathrm{AlO}_{4}$ & $20 \pm 1$ & $23 \pm 1$ \\
\hline & & & 1/2 QMAS & 52 & 6.8 & 0.00 & - & $\mathrm{AlO}_{5}$ & $19 \pm 1$ & $22 \pm 1$ \\
\hline & & & 1/2 QMAS & 44 & 7.8 & 0.75 & - & $\mathrm{AlO}_{5}$ & $14 \pm 1$ & $16 \pm 1$ \\
\hline & & & 1/2 QMAS & 9 & 5.8 & 0.38 & - & $\mathrm{AlO}_{6}$ & $33 \pm 1$ & $39 \pm 1$ \\
\hline & & & Gaussian & 14 & - & - & 6.13 & $\mathrm{Al}_{2} \mathrm{O}_{3}$ & $14 \pm 1$ & - \\
\hline \multirow[t]{6}{*}{ B12 } & 80.4 & 19.6 & 1/2 QMAS & 72 & 9.1 & 0.44 & - & $\mathrm{AlO}_{4}$ & $21 \pm 1$ & $23 \pm 1$ \\
\hline & & & 1/2 QMAS & 52 & 6.8 & 0.04 & - & $\mathrm{AlO}_{5}$ & $20 \pm 1$ & $21 \pm 1$ \\
\hline & & & 1/2 QMAS & 45 & 8.0 & 0.76 & - & $\mathrm{AlO}_{5}$ & $16 \pm 1$ & $17 \pm 1$ \\
\hline & & & Gaussian & 10 & - & - & 0.32 & $\mathrm{AlO}_{6}$ & $1 \pm 1$ & $1 \pm 1$ \\
\hline & & & 1/2 QMAS & 9 & 5.9 & 0.38 & - & $\mathrm{AlO}_{6}$ & $36 \pm 1$ & $39 \pm 1$ \\
\hline & & & Gaussian & 13 & - & - & 1.16 & $\mathrm{Al}_{2} \mathrm{O}_{3}$ & $7 \pm 1$ & - \\
\hline \multirow[t]{5}{*}{ B14 } & 57.7 & 42.3 & 1/2 QMAS & 71 & 9.1 & 0.44 & - & $\mathrm{AlO}_{4}$ & $22 \pm 1$ & $22 \pm 1$ \\
\hline & & & 1/2 QMAS & 52 & 6.8 & 0.04 & - & $\mathrm{AlO}_{5}$ & $20 \pm 1$ & $20 \pm 1$ \\
\hline & & & 1/2 QMAS & 45 & 8.0 & 0.76 & - & $\mathrm{AlO}_{5}$ & $18 \pm 1$ & $18 \pm 1$ \\
\hline & & & Gaussian & 10 & - & - & 0.20 & $\mathrm{AlO}_{6}$ & $1 \pm 1$ & $1 \pm 1$ \\
\hline & & & 1/2 QMAS & 9 & 5.9 & 0.37 & - & $\mathrm{AlO}_{6}$ & $40 \pm 1$ & $40 \pm 1$ \\
\hline
\end{tabular}

$\delta_{\text {iso }}=$ chemical shift, $C_{\mathrm{Q}}=$ quadrupole coupling constants, $\eta_{\mathrm{Q}}=$ asymmetry parameter 

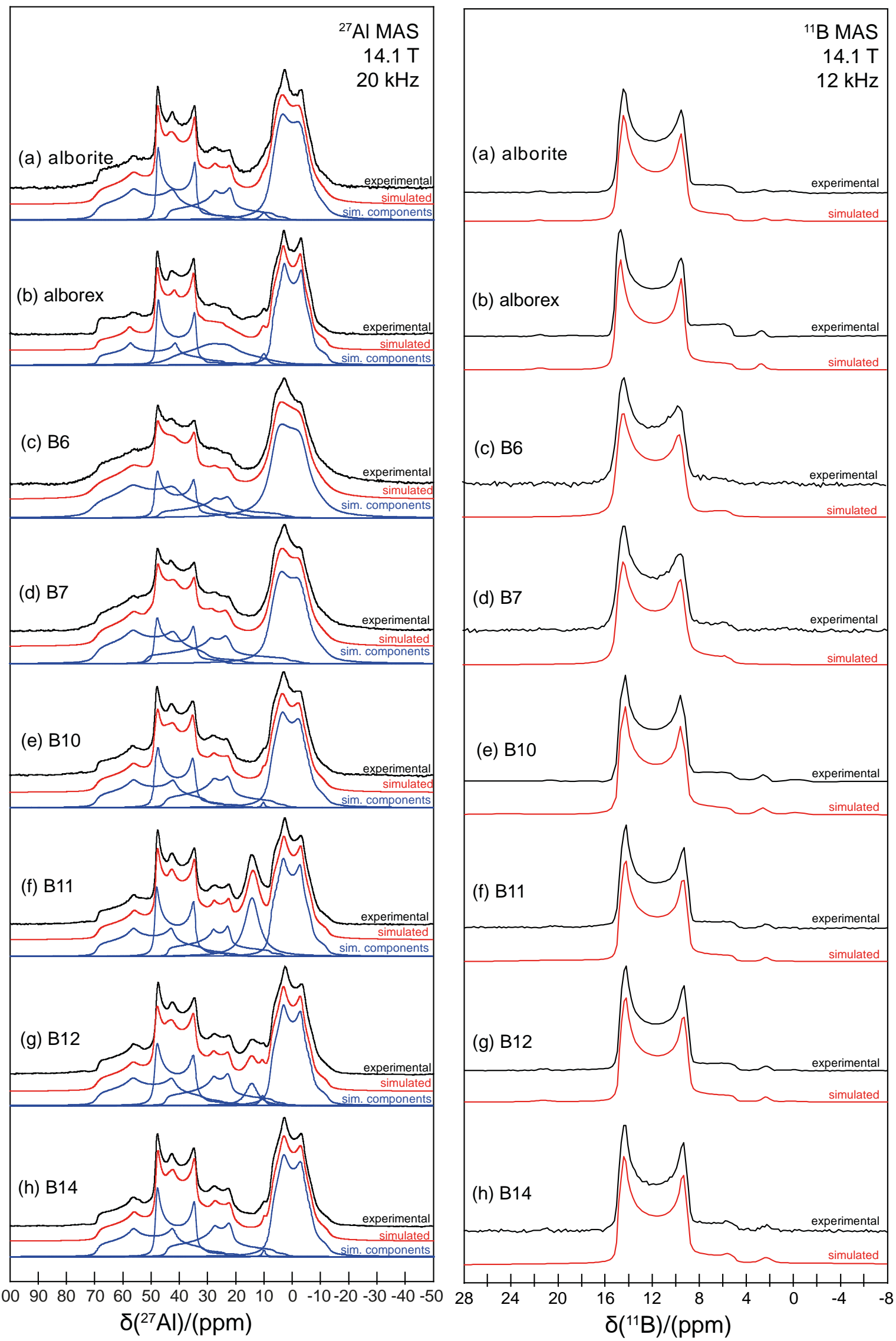

Figure 3. Experimental ${ }^{27} \mathrm{Al}$ MAS NMR (left) spectra and ${ }^{11} \mathrm{~B}$ MAS NMR (right) spectra for $A_{9} B_{2} / A_{5} B$ series, displayed with the simulations of the corresponding spectra and the simulated components. 
(a) alborite

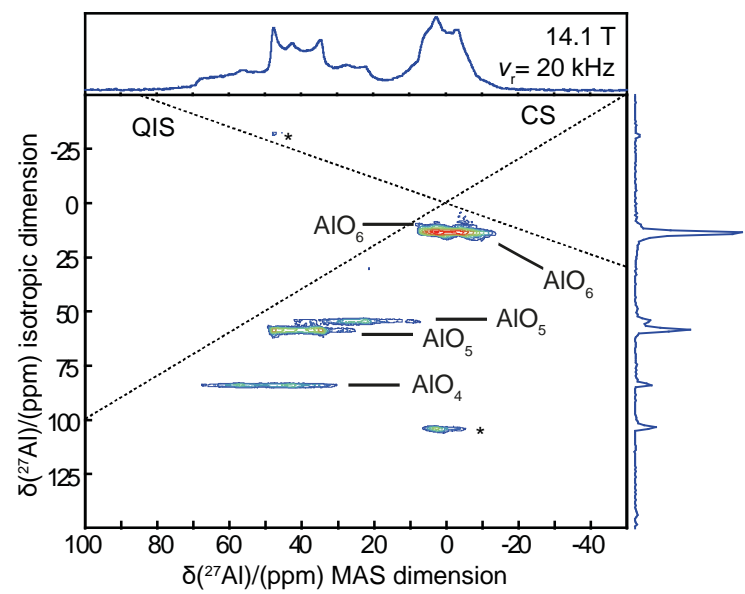

(c) B11

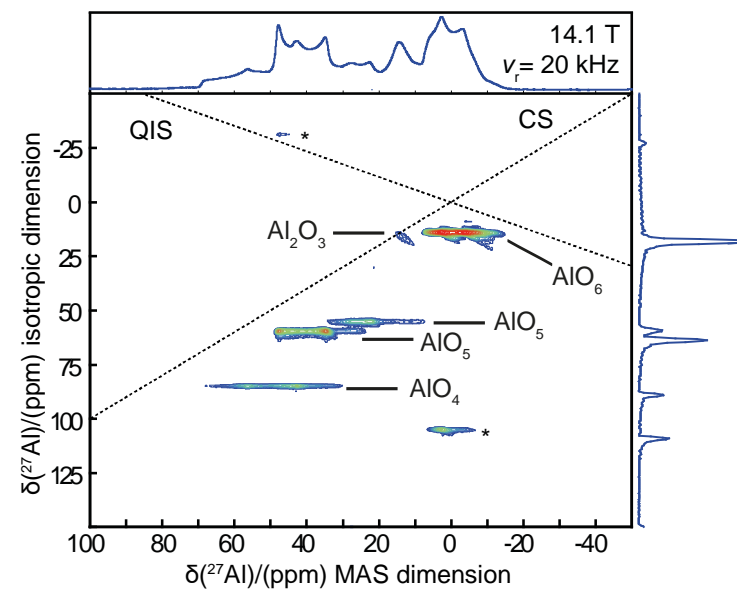

(b) B6

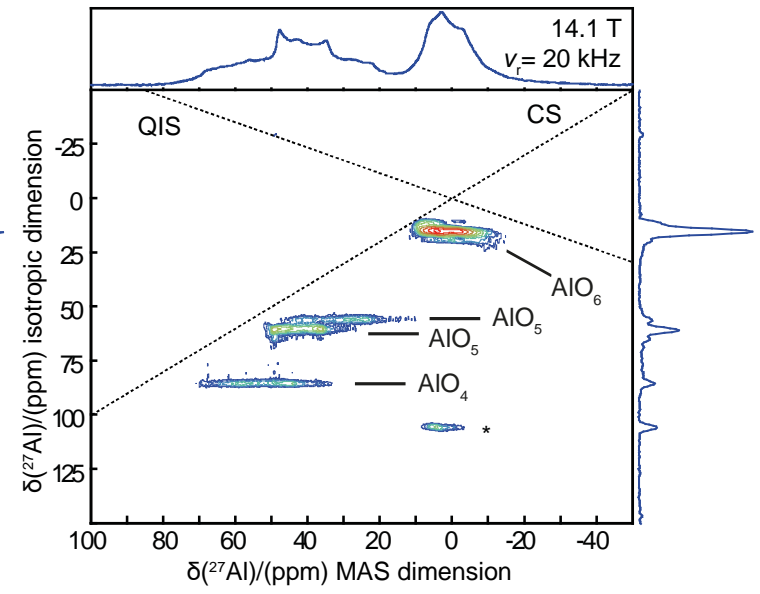

(d) B14

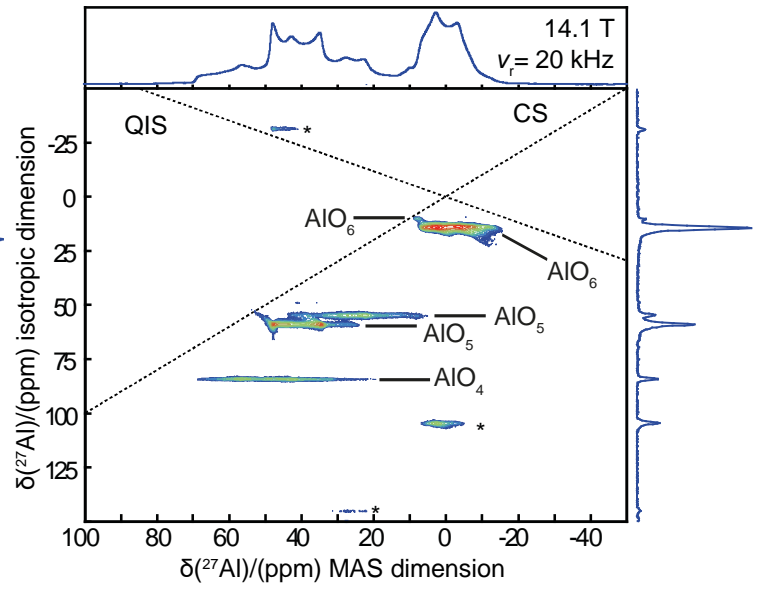

Figure 4. Experimental ${ }^{27} \mathrm{Al}$ MQMAS NMR data for the commercial product Alborite and for synthesized samples, using the nitrate decomposition method or the solid state reaction, respectively.

The ${ }^{27} \mathrm{Al}$ MAS NMR spectra show $\mathrm{Al}$ to be present in three different coordination environments, $\mathrm{AlO}_{4}, \mathrm{AlO}_{5}$ and $\mathrm{AlO}_{6}$, in which $\mathrm{AlO}_{5}$ resides on two different sites. The same resonances were also observed by Fisch et al. [15]. An additional weak extra peak is observed representing a second $\mathrm{AlO}_{6}$ site correlating with the formation of 4-fold coordinated boron.

Sample B6 and B7 show a broadening of the line shapes in the ${ }^{27} \mathrm{Al}$ MAS NMR spectra and a varying ratio of $\mathrm{AlO}_{4} / \mathrm{AlO}_{5}$ compared to the remaining samples. This might be explained by 
disorder effects in the crystal structure, as also expected from the X-ray diffraction pattern of these two samples (see part X-ray powder diffraction).

FTIR and Raman spectra are collected for samples of the $A_{9} B_{2} / A_{5} B$ series. The spectra are almost identical within the $\mathrm{A}_{9} \mathrm{~B}_{2} / \mathrm{A}_{5} \mathrm{~B}$ series, therefore IR and Raman spectra of one selected sample of the $A_{9} B_{2} / A_{5} B(B 10)$ series are shown in comparison to those of a sample from the $\mathrm{A}_{2} \mathrm{~B}$ series (A4) containing both $\mathrm{BO}_{3}$ - and $\mathrm{BO}_{4}$ - groups (Fig. 5).

According to Fisch et al. [15], the characteristic asymmetric stretching vibrations of a $\mathrm{BO}_{3}$ group occur predominantly in IR spectra $\left(1200-1450 \mathrm{~cm}^{-1}\right)$ whereas the symmetric stretching vibrations occur predominantly in Raman spectra $\left(950-1050 \mathrm{~cm}^{-1}\right)$. These modes are observed in the spectra for the samples of both series, $A_{2} B$ and $A_{9} B_{2} / A_{5} B$ (Fig. 5).

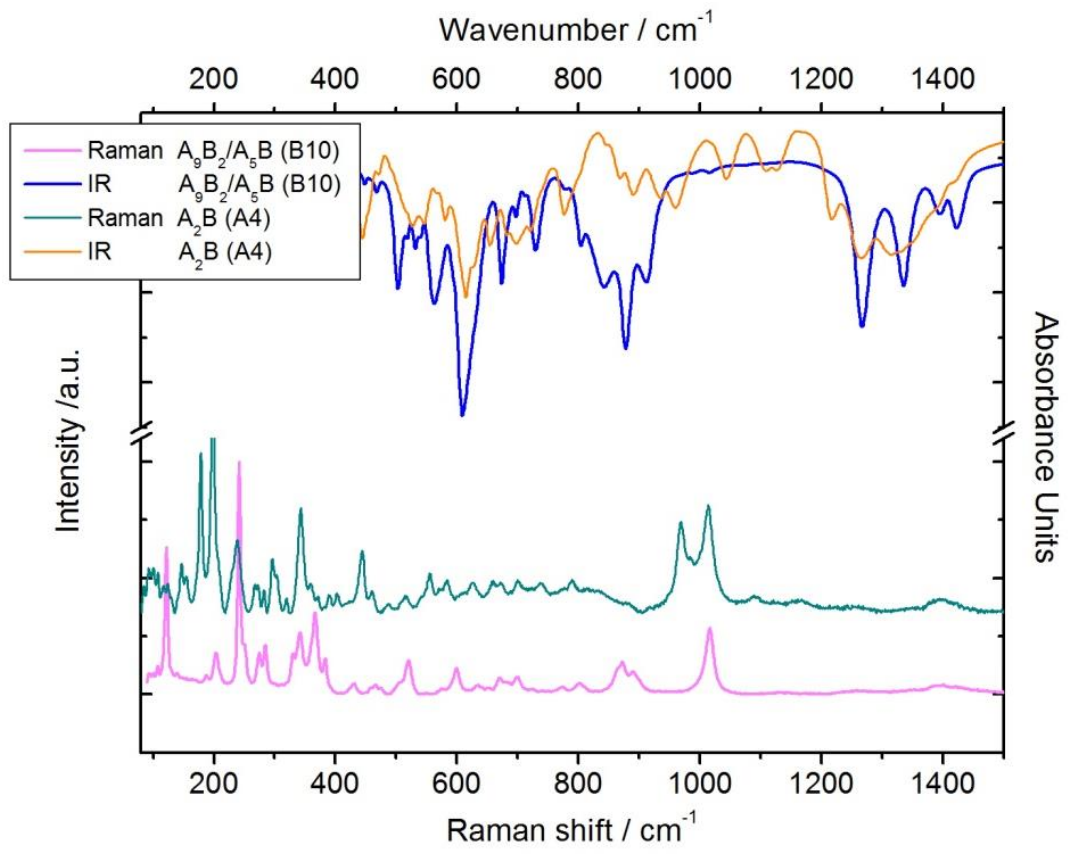

Figure 5. IR (top) and Raman (bottom) spectra of representative samples of the $A_{9} B_{2} / A_{5} B$ and $A_{2} B$ series, respectively. IR spectrum of $A_{2} B$ is double raised pictured.

A second strong mode in the Raman spectra of sample $A 4\left(A_{2} B\right)$ to the left of the $\mathrm{BO}_{3}$ band can be assigned to $\mathrm{BO}_{4}$ [29]. Alike the finding of Fisch et al. [15] for an aluminum borate sample with $\mathrm{A}_{9} \mathrm{~B}_{2} / \mathrm{A}_{5} \mathrm{~B}$ structure, this band does not occur in the spectra for the sample B10 
$\left(A_{9} B_{2} / A_{5} B\right)$. However, the asymmetric Raman peak shape of the absorption band at $1016 \mathrm{~cm}^{-1}$ (sample B10) might indicate both, $\mathrm{BO}_{3}$ and $\mathrm{BO}_{4}$ (Fig. 6). As observed by Fisch et al. [15], the IR-active asymmetric stretching vibrations of $\mathrm{BO}_{4}$ expected at $950-1200 \mathrm{~cm}^{-1}$ [15] are only verified for the $\mathrm{A}_{2} \mathrm{~B}$ sample $\mathrm{A} 4$.

The bending symmetric vibrations of $\mathrm{BO}_{3}$ was determined by Griesser et al. [27] for borondoped mullites and $\mathrm{Al}_{18} \mathrm{~B}_{4} \mathrm{O}_{33}$ to occur in the spectral region of $674-689 \mathrm{~cm}^{-1}$ and the bending asymmetric vibration of $\mathrm{BO}_{3}$ in the spectral region of $555-562 \mathrm{~cm}^{-1}$. Distinction between $\mathrm{B}-\mathrm{O}$ and $\mathrm{Al}-\mathrm{O}$ stretching in this region is difficult as the frequency of the $\mathrm{AlO}_{\mathrm{x}}$ polyhedral features are also expected in the region $<900 \mathrm{~cm}^{-1}[15]$.

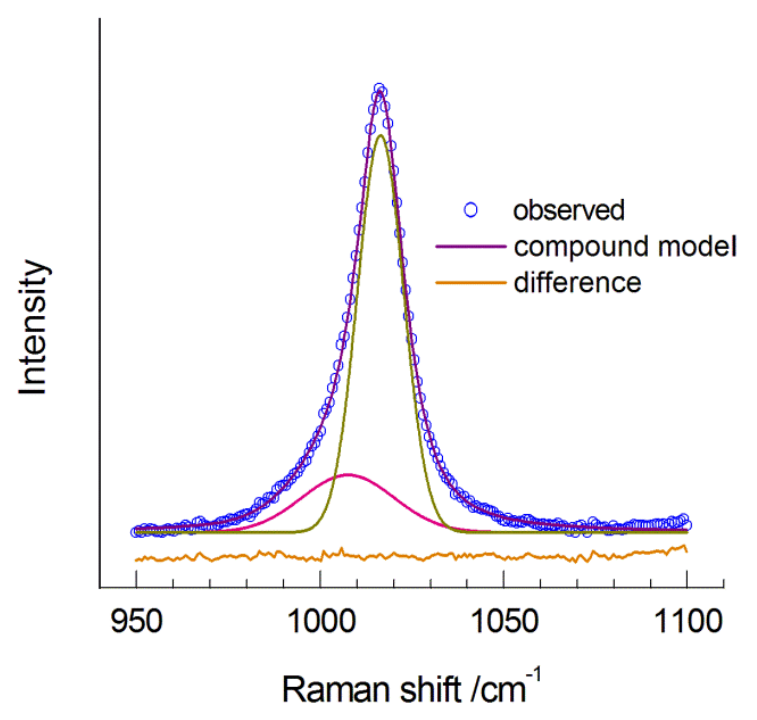

Figure 6. Selective region of Raman spectra of a representative sample of the $A_{9} B_{2} / A_{5} B$ series (B10), showing the characteristic peak of the $\mathrm{BO}_{3}$ group at about $1016(1) \mathrm{cm}^{-1}$; the asymmetric peak shape indicates the presence of $\mathrm{a} \mathrm{BO}_{4}$ group fitted at about $1007(1) \mathrm{cm}^{-1}$.

\subsection{Thermal stability of $\mathrm{Al}_{20-x} \mathrm{~B}_{4+\mathrm{x}} \mathrm{O}_{36}$}

The thermal stability was investigated by DTA for selected samples. The TG indicates a minor weight loss between room temperature and $1773 \mathrm{~K}$, more pronounced in the HT-region above $1473 \mathrm{~K}$. In additional experiments a continuous weight loss is observed within a $5 \mathrm{~h}$ 
isothermal segment at $1673 \mathrm{~K}$ (Tab. 8). In the resulting products significant amounts of $\alpha$ $\mathrm{Al}_{2} \mathrm{O}_{3}$ were additionally found indicating the weight loss to be caused by loss of boron. For samples synthesized using the nitrate decomposition method, an almost identical weight loss is observed upon heating in the isothermal segment. This, together with an increasing amount of $\mathrm{Al}_{2} \mathrm{O}_{3}$ in the products with decreasing initial boron content, indicates differences in the chemical composition.

Table 8. Weight loss within the $5 \mathrm{~h}$ isothermal segment at $1673 \mathrm{~K}$ and the amount of $\alpha-\mathrm{Al}_{2} \mathrm{O}_{3}$ in the products of thermal analysis; small variations of the weight $( \pm 0.3 \mathrm{wt} \%)$ in the heating segment up to $1473 \mathrm{~K}$ are caused by the instrument and /or surface water.

\begin{tabular}{ccccc}
\hline Exp. & $\begin{array}{c}\text { Initial } \\
\mathrm{Al}_{2} \mathrm{O}_{3} / \mathrm{B}_{2} \mathrm{O}_{3}\end{array}$ & Method & $\begin{array}{c}\text { Weight loss } / w t \% \\
\text { Isothermal segment }\end{array}$ & $\begin{array}{c}\text { Content of } \\
\alpha-\mathrm{Al}_{2} \mathrm{O}_{3} / \mathrm{wt} \%\end{array}$ \\
\hline $\mathrm{B} 6$ & $5.0: 1.1$ & $\mathrm{ND}$ & 3.5 & 24 \\
$\mathrm{~B} 7$ & $4.5: 1.1$ & $\mathrm{ND}$ & 3.8 & 22 \\
$\mathrm{~B} 10$ & $1.0: 1.1$ & $\mathrm{ND}$ & 3.5 & 17 \\
$\mathrm{~B} 12$ & $4.5: 1.1$ & $\mathrm{~S}$ & 2.6 & $16^{*}$ \\
$\mathrm{~B} 14$ & $1.5: 1.1$ & $\mathrm{~S}$ & 2.0 & 14 \\
$\mathrm{~B} 15$ & $1.0: 1.1$ & $\mathrm{~S}$ & 2.0 & 14 \\
& & & & \\
Alborite & unknown & & 3.5 & 29 \\
Alborex & unknown & & \\
\hline ND: nitrate decomposition method; S: solid-state reaction; \\
* refined from a measurement on a slurry
\end{tabular}

Assuming a composition of $\mathrm{Al} / \mathrm{B}=5: 1.1$, the expected amount of $\alpha-\mathrm{Al}_{2} \mathrm{O}_{3}$ would be about $17 \mathrm{wt} \%$ for a weight loss of $3.6 \mathrm{wt} \%$. The determined amount of $24 \mathrm{wt} \% \alpha-\mathrm{Al}_{2} \mathrm{O}_{3}$ for a sample with this initial composition (B11) is clearly higher than the calculated one. This might be explained by boron which volatized during the heating to $1673 \mathrm{~K}$. The DSC measurements do not show any signal, since a continuous weight loss over a period of time as observed here. An extended heating experiment was performed on a selected sample (B10) at $1673 \mathrm{~K}$ using a covered corundum crucible (heating/cooling rate: $5 \mathrm{~K} / \mathrm{min}$ ), yielding pure $\alpha-\mathrm{Al}_{2} \mathrm{O}_{3}$ [40] as decomposition product after a heating period of $48 \mathrm{~h}$. The experiments confirm the decomposition temperature observed by Scholze [21]. A decomposition of the alumina borate 
phase at $1473 \mathrm{~K}$ might be expected for an extended heating period (about $16.73 \mathrm{wt} \% \alpha-\mathrm{Al}_{2} \mathrm{O}_{3}$ after 44h) supporting the study of Rymon-Lipinski et al. [22] describing a decomposition of $\mathrm{A}_{9} \mathrm{~B}_{2}$ at $1473 \mathrm{~K}$ to $\mathrm{Al}_{2} \mathrm{O}_{3}$ and liquid $\mathrm{B}_{2} \mathrm{O}_{3}$. The thermal analysis clearly suggests that the phase diagram [7] may need to be reevaluated.

\subsection{Crystal-chemical characterization of $\mathrm{Al}_{4} \mathrm{~B}_{2} \mathrm{O}_{9}$}

\section{Diffraction}

X-ray diffraction patterns are collected for samples A1-A4 synthesized with different initial $\mathrm{Al} / \mathrm{B}$ ratios, confirming pure phases. The lattice parameters and the average crystallite size were refined using a Pawley fit. A slight trend of a decreasing cell volume is observed for increasing initial boron content (Tab. 9). These minor variations might be caused by small structural differences (see part spectroscopy). As observed for the $A_{9} B_{2} / A_{5} B$ series the crystallite size increases with increasing initial boron content. No amorphous boron oxide compounds are expected to be in any sample, as repeated measurements after two years, keeping the sample in open conditions, do not show impurities of boric acid.

Table 9. Refined lattice parameters and crystallite sizes for the samples of the $A_{2} B$ series.

\begin{tabular}{ccccccccc}
\hline Exp. & $\begin{array}{c}\mathrm{Al}_{2} \mathrm{O}_{3} \\
/ \mathrm{wt} \%\end{array}$ & $\begin{array}{c}\mathrm{B}_{2} \mathrm{O}_{3} \\
/ \mathrm{wt} \%\end{array}$ & $\begin{array}{c}\text { Lattice } \\
\text { parameter } \\
a / \mathrm{pm}\end{array}$ & $\begin{array}{c}\text { Lattice } \\
\text { parameter } \\
b / \mathrm{pm}\end{array}$ & $\begin{array}{c}\text { Lattice } \\
\text { parameter } \\
c / \mathrm{pm}\end{array}$ & $\begin{array}{c}\text { Lattice } \\
\text { parameter } \\
\beta /{ }^{\circ}\end{array}$ & $\begin{array}{c}\text { Cell volume } \\
V / 10^{6} \mathrm{pm}^{3}\end{array}$ & $\begin{array}{c}\text { Crystallite } \\
\text { size } / \mathrm{nm}\end{array}$ \\
\hline $\mathrm{A} 1$ & 70 & 30 & $1481.8(2)$ & $554.44(6)$ & $1509.5(2)$ & $90.752(4)$ & $1240.1(3)$ & $37.3(4)$ \\
$\mathrm{A} 2$ & 65 & 35 & $1481.8(4)$ & $554.6(1)$ & $1508.3(3)$ & $90.775(6)$ & $1239.4(5)$ & $36.9(4)$ \\
$\mathrm{A} 3$ & 60 & 40 & $1481.8(2)$ & $554.54(4)$ & $1507.1(1)$ & $90.831(3)$ & $1238.2(2)$ & $74.7(9)$ \\
$\mathrm{A} 4$ & 35 & 65 & $1481.3(1)$ & $554.18(3)$ & $1505.93(9)$ & $90.930(2)$ & $1236.1(1)$ & $135(2)$ \\
$\mathrm{A} 5 *$ & 31 & 69 & $1479.9(1)$ & $554.03(3)$ & $1597.3(3)$ & $90.973(3)$ & $1233.6(1)$ & $84(27)$ \\
\hline
\end{tabular}

*result from neutron powder diffraction data refinement

Rietveld refinements on neutron diffraction data were performed on sample A5 (Figure 7). Using the crystal-structure model of Fischer et al. [24], the lattice parameters and all structural parameters were refined. The isotropic displacement parameters were constrained to be equal 
within a group of elements, respectively. The refinement confirms the basic structure determined from X-ray powder diffraction [24]. A very short distance of 212(5) pm is refined for the $\mathrm{O} 10$ - O10 distance. However, the disorder of the oxygen atoms has a stronger impact on neutron diffraction data compared to X-ray powder diffraction data due to the difference in the scattering length which is more pronounced in neutron data.

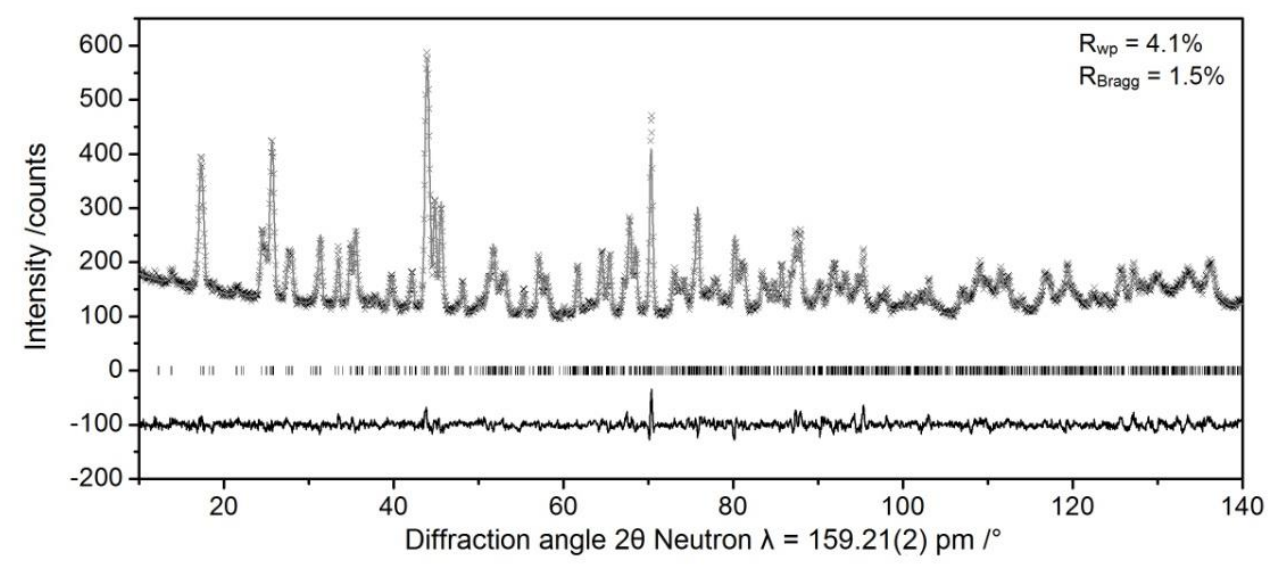

Figure 7. Rietveld plot of the refined neutron powder diffraction data at RT, using the original crystal-structure model of [24]. Observed intensities (black crosses), calculated intensities (gray curve), positions of reflections (tick marks) and the difference curve between observed and calculated data (lower curve) are shown.

To investigate the oxygen disorder different models were tested: (i) the occupancies of the channel oxygen atoms $\mathrm{O} 10$ and $\mathrm{O} 5$ were refined constrained to be a sum of 1 , showing a preference for the $\mathrm{O} 10$ site $(\mathrm{Occ}(\mathrm{O} 10)=0.61(3)$; $\mathrm{Occ}(\mathrm{O} 5)=0.39(3))$; (ii) vacancies were refined on the $\mathrm{O} 10$ site removing the $\mathrm{O} 5$ site, resulting in a decreased occupancy of $0.78(2)$ for the $\mathrm{O} 10$ site. Both models indicate the existence of both atoms O5 and O10. DifferenceFourier calculations were performed using the neutron-diffraction refinement. The isotropic displacement parameters were kept from the model [24], as no reasonable refinement of these values could be achieved. Highest maximum corresponds to the B2 position $(x=0.37$, $y=0.00, z=0.13$ ) followed by maxima which could be assigned to the remaining three boron atoms and a $5^{\text {th }}$ maximum $(x=0.37, y=0.50, z=0.13)$ shifted by 0.5 in $\mathbf{b}$ direction compared 
to the $\mathrm{B} 2$ position. The following maximum $(x=0.28, y=0.50, z=0.26)$ is close to the $\mathrm{O} 1$ site determined by Fischer et al. [24].

As additional approach, transmission electron microscope (TEM) was applied to investigate the crystal structure of sample A4. Three-dimensional electron diffraction data were collected from single crystals by automated diffraction tomography (ADT) [41]. The reconstruction of the $3 \mathrm{D}$ reciprocal volume confirm the monoclinic unit cell in space group $C 2 / m$ with $a=1488 \mathrm{pm}, b=553 \mathrm{pm}, c=1502 \mathrm{pm}$ and $\beta=90.6^{\circ}$ (Fig. 8). The structure solution for ordered crystals clearly shows one fully occupied position of $\mathrm{O} 10$ but no significant signal for the second postulated oxygen $\mathrm{O} 5$ in the channel. The diffraction data exhibit diffuse scattering along $\mathbf{b}$ direction in some crystals, assigned to a superstructure with a threefold $\mathbf{b}$-axis and additional disorder within the ac plane. Theses domains might bear a disordered distribution of O5 and O10. It is likely that domains with a disordered superstructure occur independent from the initial composition. This explains why a satisfactory refinement with an average structure model from powder diffraction refinements cannot be obtained.

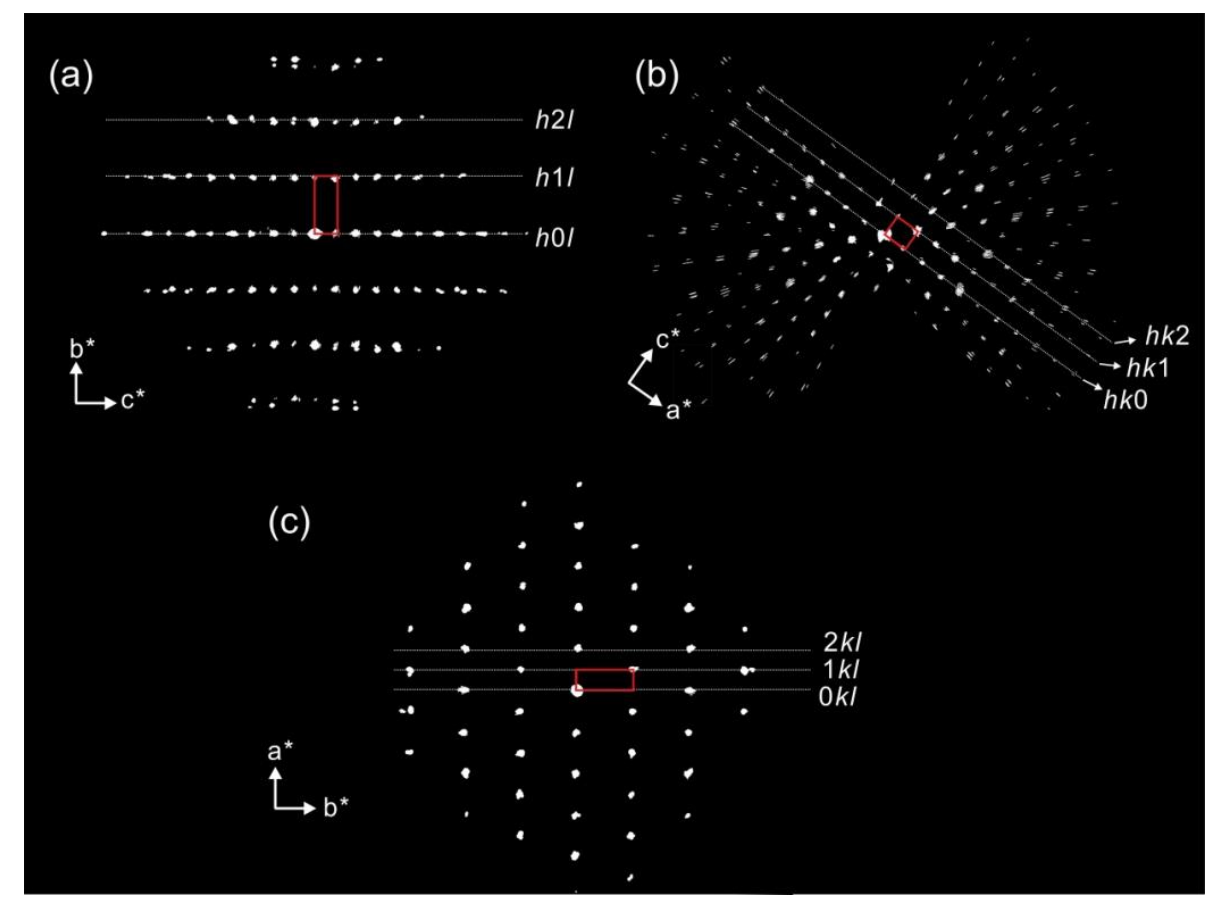

Figure 8. Projections of three-dimensional electron diffraction space of $\mathrm{Al}_{4} \mathrm{~B}_{2} \mathrm{O}_{9}$ along the main directions. 
The atomic parameters of sample A4 determined from ADT data of ordered crystals are listed in Table 10; a projection of the crystal structure is shown in Figure 9. The mean distances of the $\mathrm{B}-\mathrm{O}$ groups in the range of $131 \mathrm{pm}-141 \mathrm{pm}$ confirm the B1, B3 and B4 atoms to occur in a nearly planar trigonal coordination. Full occupancy of the $\mathrm{O} 10$ site causes the $\mathrm{B} 2$ to be exclusively 4-fold coordinated (B2 - O13: $141 \mathrm{pm}, \mathrm{B} 2$ - O10: $141 \mathrm{pm}, 2 \mathrm{x}$ B2 - O7: 143 pm). Fischer et al. [24] discussed their model with a short $\mathrm{O} 10$ - $\mathrm{O} 7$ distance $(212 \mathrm{pm})$ in the $\mathrm{Al}_{3} \mathrm{O}_{4}$ tetrahedron. The electron-diffraction data yield an interatomic distance of $234 \mathrm{pm}$ for $\mathrm{O} 10$ $\mathrm{O} 7$ in the $\mathrm{Al}_{3} \mathrm{O}_{5}$ polyhedron along with a short distance of $225 \mathrm{pm}$ for $\mathrm{O} 10-\mathrm{O} 10$ and $223 \mathrm{pm}$ for $\mathrm{O} 10$ - O13. In a regular tetrahedron an $\mathrm{O}-\mathrm{O}$ distance of $241 \mathrm{pm}$ would be expected for a B-O distance of $148 \mathrm{pm}$. However, for borasilite [42], being closely related to the $\mathrm{Al}_{4} \mathrm{~B}_{2} \mathrm{O}_{9}$ structure, a similar interatomic distance $(225 \mathrm{pm})$ is observed for $\mathrm{O} 10-\mathrm{O} 10$ in the $\mathrm{Al}_{3} \mathrm{O}_{5}$ group. The $\mathrm{Al} 3$ will be exclusively 5-fold coordinated in case of a fully occupied O10 site.

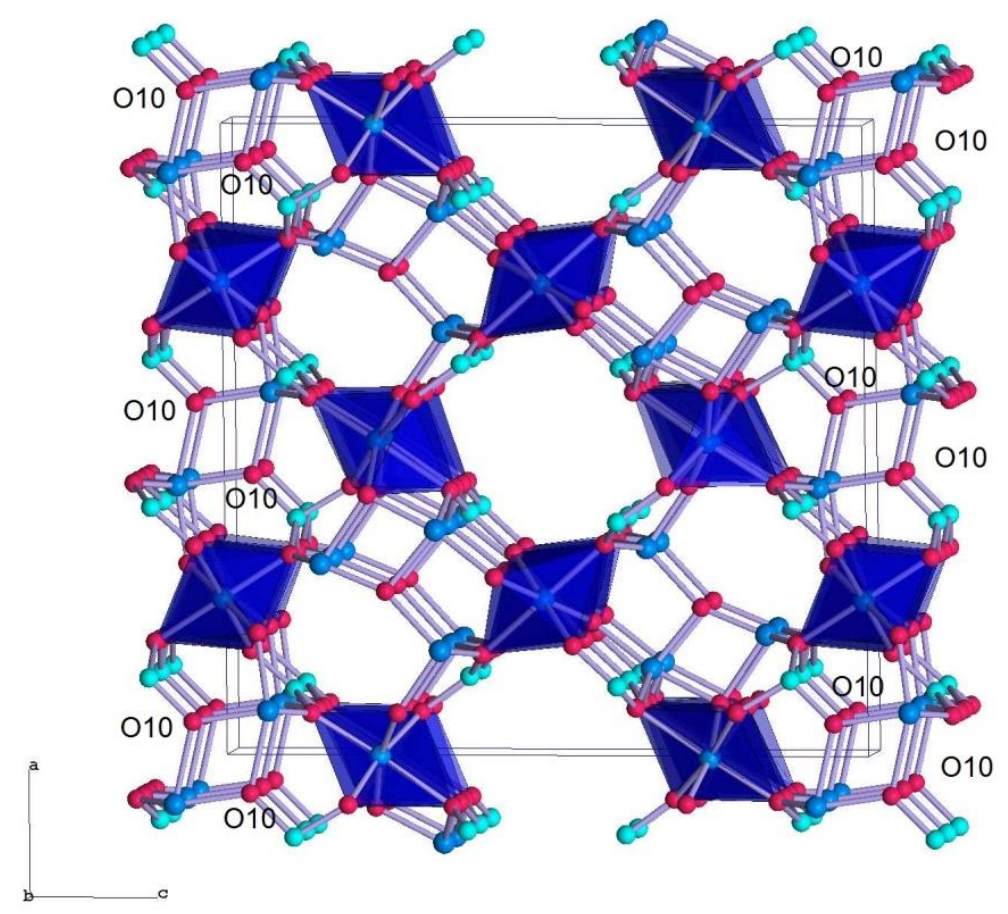

Figure 9. Crystal structure of mullite-type aluminoborate $\mathrm{Al}_{4} \mathrm{~B}_{2} \mathrm{O}_{9}$. Blue polyhdedra: $\mathrm{AlO}_{6}$ octahedra, light blue dots: $\mathrm{Al}$ (in $\mathrm{AlO}_{4^{-}}$or $\mathrm{AlO}_{5}$-polyhedra), green dots: $\mathrm{B}$ (in $\mathrm{BO}_{3-}$ or $\mathrm{BO}_{4}$ polyhedra). 
Table 10. Crystallographic data of $A_{2} B$ obtained from electron diffraction data (space group $C 2 / m$ with $a=1488 \mathrm{pm}, b=553 \mathrm{pm}, c=1502 \mathrm{pm}$ and $\beta=90.6^{\circ}$ ), representing the domains with an ordered distribution of atoms, without the channel oxygen atom O5.

\begin{tabular}{|c|c|c|c|c|c|c|c|}
\hline Atom & multiplicity & Wyckoff & $x$ & $y$ & $z$ & Occu. & $B_{\text {iso }} / 10^{4} \mathrm{pm}^{2}$ \\
\hline Al1 & 4 & $i$ & $0.8627(8)$ & 0 & $0.3351(8)$ & 1 & $1.4(2)$ \\
\hline $\mathrm{A} 12$ & 4 & $i$ & $0.809(1)$ & 0 & $0.1556(9)$ & 1 & $2.3(2)$ \\
\hline $\mathrm{Al} 3$ & 4 & $i$ & $0.573(1)$ & 0 & $0.073(1)$ & 1 & $2.6(3)$ \\
\hline Al4 & 4 & $i$ & $0.670(1)$ & 0 & $0.343(1)$ & 1 & $2.4(3)$ \\
\hline $\mathrm{A} 15$ & 8 & $j$ & $0.0007(4)$ & $0.741(1)$ & $0.2425(5)$ & 1 & $0.8(2)$ \\
\hline Al6 & 4 & $e$ & $1 / 4$ & $1 / 4$ & 0 & 1 & $1.9(2)$ \\
\hline Al7 & 4 & $f$ & $1 / 4$ & $1 / 4$ & $1 / 2$ & 1 & $2.3(2)$ \\
\hline B1 & 4 & $i$ & $0.103(2)$ & 0 & $0.108(2)$ & 1 & $0.8(4)$ \\
\hline B2 & 4 & $i$ & $0.376(1)$ & 0 & $0.114(1)$ & 1 & $3.3(7)$ \\
\hline B3 & 4 & $i$ & $0.1252(2)$ & 0 & $0.3708(2)$ & 1 & $2.8(6)$ \\
\hline B4 & 4 & $i$ & $0.387(2)$ & 0 & $0.388(2)$ & 1 & $1.7(5)$ \\
\hline O1 & 4 & $i$ & $0.762(1)$ & 0 & $0.267(1)$ & 1 & 2.6(4) \\
\hline $\mathrm{O} 2$ & 4 & $i$ & $0.787(1)$ & 0 & $0.434(1)$ & 1 & 2.9(4) \\
\hline $\mathrm{O} 3$ & 4 & $i$ & $0.918(1)$ & 0 & $0.223(1)$ & 1 & 2.4(4) \\
\hline $\mathrm{O} 4$ & 8 & $j$ & $0.9219(8)$ & $0.7120(2)$ & $0.3560(8)$ & 1 & $1.7(2)$ \\
\hline O6 & 4 & $i$ & $0.3190(9)$ & 0 & $0.451(1)$ & 1 & $0.8(2)$ \\
\hline O7 & 8 & $j$ & $0.8183(8)$ & $0.7049(2)$ & $0.1041(8)$ & 1 & $1.8(2)$ \\
\hline O8 & 4 & $i$ & $0.697(1)$ & 0 & $0.058(1)$ & 1 & $1.7(3)$ \\
\hline O9 & 8 & $j$ & $0.0679(8)$ & $0.7774(3)$ & $0.1367(9)$ & 1 & $1.7(2)$ \\
\hline $\mathrm{O} 10$ & 4 & $i$ & $0.443(1)$ & 0 & $0.049(1)$ & 1 & $2.8(4)$ \\
\hline O11 & 8 & $j$ & $0.6611(9)$ & $0.2822(3)$ & $0.405(1)$ & 1 & $2.4(2)$ \\
\hline $\mathrm{O} 12$ & 4 & $i$ & $0.575(1)$ & 0 & $0.276(1)$ & 1 & $1.6(3)$ \\
\hline $\mathrm{O} 13$ & 4 & $i$ & $0.426(1)$ & 0 & $0.195(1)$ & 1 & $1.2(2)$ \\
\hline O14 & 4 & $i$ & $0.069(1)$ & 0 & $0.302(1)$ & 1 & $1.8(3)$ \\
\hline O15 & 4 & $i$ & $0.834(1)$ & 0 & $0.962(1)$ & 1 & $1.4(3)$ \\
\hline
\end{tabular}

Peacor et al. [42] described the $\mathrm{O} 10$ position in borasilite to be disordered introducing a 'split' atom pair consisting of O10A $(\mathrm{x}=0.444, \mathrm{y}=0, \mathrm{z}=0.049)$ and $\mathrm{O} 10 \mathrm{~B}(\mathrm{x}=1 / 2, \mathrm{y}=0, \mathrm{z}=0)$; the latter one residing in an inversion center. Both oxygen atoms $(\mathrm{O} 10 \mathrm{~A}$ and $\mathrm{O} 10 \mathrm{~B})$ are in the coordination sphere of the $\mathrm{Al} 3\left(\mathrm{Al}_{3} \mathrm{O}_{5}\right.$ polyhedron), but too close for a simultaneous occupancy. A shift of the O10B by 0.5 in b direction causes a shortened Al-O distance of 
146.4(4) $\mathrm{pm}$ in the $\mathrm{Al}_{3} \mathrm{O}_{5}$ [42], thus leading to the assumption that a substitution of $\mathrm{B}^{3+}$ for $\mathrm{Al}^{3+}$ on the $\mathrm{Al} 3$ site might be possible. The fifth maximum found in the Fourier calculations $(x=0.37, y=0.50, z=0.13)$ might be a result from a disordered configuration. However, structural details discussing the order and disorder configuration are given in Zhao et al. [43].

\section{Spectroscopy}

The ${ }^{11}$ B MAS NMR data (Fig. 10, left) confirm boron to be present in trigonal (site B1, B3, B4) and different tetrahedral sites (site $\mathrm{B} 2$ and possibly B3). The trigonal planar $\mathrm{BO}_{3}$ position was fitted by a second order broadened quadrupolar resonance with $C_{\mathrm{Q}}$ of $\sim 2.6 \mathrm{MHz}, \delta_{\text {iso }}$ of $\sim$ $16.8 \mathrm{ppm}$ and $\eta_{\mathrm{Q}}$ of $\sim 0.11$. However, the different $\mathrm{BO}_{3}$ sites might be too similar to be distinguished in the NMR spectra. The $\mathrm{BO}_{4}$ positions were simulated with Gaussian lineshapes. Similar to the $A_{9} B_{2} / A_{5} B$ series a trend of slightly increasing relative ratios of the site occupancy of 4-coordinated $\mathrm{BO}_{4}\left(26-30 \% \mathrm{BO}_{4}\right)$ compared to the $\mathrm{BO}_{3}$ site is estimated with an increasing boron content in the precursor phase (see Tab. 11). Fischer et al. [24] determined about $20 \%$ of boron in the $\mathrm{A}_{2} \mathrm{~B}$ structure to be tetrahedrally coordinated. However, in the published model of the $\mathrm{A}_{2} \mathrm{~B}$ structure, the statistical distribution of the $\mathrm{O} 10$ atoms leads to a statistical distribution of the B2 atom on either trigonal or tetrahedral sites [24]. A full occupancy of the O10 position would cause the B2 atom to be exclusively 4-fold coordinated and therefore would yield an increased ratio of $\mathrm{BO}_{4}$ up to $25 \%$. An additional slightly increased $\mathrm{BO}_{4}$ content and small changes in the $\mathrm{BO}_{3} / \mathrm{BO}_{4}$ ratio might be explained by the slight structural changes rather than by differences in the chemical composition. Multiple $\mathrm{BO}_{4}$ peaks can be explained due to the disorder in these systems, which may also cause the B3 atom to occur in 4-fold coordination in the case of a disordered configuration of O5 and O10. 
Table 11. ${ }^{11} \mathrm{~B}$ solid state NMR parameters obtained from simulated fits samples of $A_{2} B$ series.

\begin{tabular}{|c|c|c|c|c|c|c|c|c|c|c|}
\hline \multirow[t]{2}{*}{$\#$} & \multicolumn{2}{|c|}{$\begin{array}{c}\text { initial } \\
\text { composition } \\
/ \mathrm{wt} \%\end{array}$} & \multirow[t]{2}{*}{ fit } & \multirow{2}{*}{$\begin{array}{c}\delta_{\text {iso }} \\
/ \mathbf{p p m} \\
( \pm 1) \\
\end{array}$} & \multirow{2}{*}{$\begin{array}{c}C_{\mathbf{Q}} \\
/ \mathrm{MHz} \\
( \pm 0.1) \\
\end{array}$} & \multirow{2}{*}{$\begin{array}{c}\eta \mathbf{Q} \\
( \pm 0.01) \\
\end{array}$} & \multirow{2}{*}{$\begin{array}{c}\Delta \\
\text { (width) } \\
/ \mathbf{K H z} \\
( \pm 0.1) \\
\end{array}$} & \multirow[t]{2}{*}{ species } & \multirow[t]{2}{*}{$\begin{array}{c}\text { integrated } \\
\text { intensity } \\
1 \%\end{array}$} & \multirow{2}{*}{$\begin{array}{c}\text { species } \\
\text { total } \\
\text { intensity } \\
/ \% \\
\end{array}$} \\
\hline & $\mathrm{Al}_{2} \mathrm{O}_{3}$ & $\mathrm{~B}_{2} \mathrm{O}_{3}$ & & & & & & & & \\
\hline \multirow[t]{4}{*}{ A1 } & 70 & 30 & 1/2 QMAS & 16.8 & 2.6 & 0.11 & - & $\mathrm{BO}_{3}$ & $74 \pm 1$ & $74 \pm 1$ \\
\hline & & & Gaussian & 0.5 & - & - & 0.72 & $\mathrm{BO}_{4}$ & $3 \pm 1$ & \\
\hline & & & Gaussian & -0.9 & - & - & 0.16 & $\mathrm{BO}_{4}$ & $13 \pm 1$ & $26 \pm 1$ \\
\hline & & & Gaussian & -1.3 & - & - & 0.09 & $\mathrm{BO}_{4}$ & $10 \pm 1$ & \\
\hline \multirow[t]{4}{*}{$\mathrm{A} 2$} & 65 & 35 & 1/2 QMAS & 16.8 & 2.6 & 0.11 & - & $\mathrm{BO}_{3}$ & $72 \pm 1$ & $72 \pm 1$ \\
\hline & & & Gaussian & 1.0 & - & - & 0.70 & $\mathrm{BO}_{4}$ & $3 \pm 1$ & \\
\hline & & & Gaussian & -0.9 & - & - & 0.17 & $\mathrm{BO}_{4}$ & $14 \pm 1$ & $28 \pm 1$ \\
\hline & & & Gaussian & -1.3 & - & - & 0.10 & $\mathrm{BO}_{4}$ & $11 \pm 1$ & \\
\hline \multirow[t]{4}{*}{ A 3} & 60 & 40 & 1/2 QMAS & 16.8 & 2.6 & 0.11 & - & $\mathrm{BO}_{3}$ & $71 \pm 1$ & $71 \pm 1$ \\
\hline & & & Gaussian & -0.7 & - & - & 0.55 & $\mathrm{BO}_{4}$ & $4 \pm 1$ & \\
\hline & & & Gaussian & -1.1 & - & - & 0.15 & $\mathrm{BO}_{4}$ & $9 \pm 1$ & $29 \pm 1$ \\
\hline & & & Gaussian & -1.3 & - & - & 0.10 & $\mathrm{BO}_{4}$ & $16 \pm 1$ & \\
\hline \multirow[t]{4}{*}{ A4 } & 35 & 65 & 1/2 QMAS & 16.8 & 2.6 & 0.11 & - & $\mathrm{BO}_{3}$ & $70 \pm 1$ & $70 \pm 1$ \\
\hline & & & Gaussian & -0.1 & - & - & 0.23 & $\mathrm{BO}_{4}$ & $2 \pm 1$ & \\
\hline & & & Gaussian & -1.0 & - & - & 0.12 & $\mathrm{BO}_{4}$ & $8 \pm 1$ & $30 \pm 1$ \\
\hline & & & Gaussian & -1.2 & - & - & 0.09 & $\mathrm{BO}_{4}$ & $20 \pm 1$ & \\
\hline
\end{tabular}

$\delta_{\text {iso }}=$ chemical shift, $C_{\mathrm{Q}}=$ quadrupole coupling constants, $\eta_{\mathrm{Q}}=$ asymmetry parameter

The ${ }^{27} \mathrm{Al}$ MAS NMR and ${ }^{27} \mathrm{Al}$ MQMAS NMR spectra for sample A1 and A4 are shown in Figure 10. The simulation of the ${ }^{27}$ Al MAS NMR data was performed analogously to [9]: the contours present in the $2 \mathrm{D}^{27} \mathrm{Al}$ MQMAS data and the long asymmetric tails (to higher field) of all of $1 \mathrm{D}^{27} \mathrm{Al}$ MAS NMR resonances indicate that significant distributions of quadrupolar and chemical shift parameters exist, thus implying that significant short range disorder characterizes these systems. The QuadFit program was used as it permits a distribution of quadrupolar parameters to be introduced to the modelling of the ${ }^{27} \mathrm{Al}$ MAS NMR resonances [44]. The deconvolutions of the $1 \mathrm{D}{ }^{27} \mathrm{Al}$ MAS NMR data at two fields (9.40 $\mathrm{T}$ and $14.1 \mathrm{~T}$ ) were simulated using Gaussian distributions of the quadrupolar coupling constant $\left(C_{\mathrm{Q}}\right)$ to accurately represent the disordered quadrupolar lineshapes observed. The deconvolutions were additionally constrained by simulating the MQMAS projections of each site and 
therefore invoke an accurate simulation of each spectrum for the samples analyzed with this methodology. The corresponding fit parameters are given in Table 12.

An increasing disorder is observed as compared to the $A_{9} B_{2} / A_{5} B$ related samples. Six independent $\mathrm{Al}$ sites can be distinguished in different coordination environments: one 4-fold coordinated site $\left(\mathrm{AlO}_{4}\right)$, three 5-fold coordinated sites $\left(\mathrm{AlO}_{5}\right)$ and two 6-fold coordinated sites $\left(\mathrm{AlO}_{6}\right)$. The latter one can be better described with three separate species as determined from the diffraction experiments; however, this could not be resolved exactly from the NMR spectra. The determined intensity ratio of tetrahedra / octahedra is about 50:50, similar to our previous determination for a sample of $\mathrm{A}_{2} \mathrm{~B}$ structure [24]. However, these data give an improvement on the previously published material [24] as we can clearly distinguish the four non-octahedral resonances. The determined ratio of the different $\mathrm{Al}$ sites is nearly independent from the initial composition.

Table 12. ${ }^{27} \mathrm{Al}$ solid state NMR parameters obtained from simulated fits for samples of $A_{2} B$ series.

\begin{tabular}{|c|c|c|c|c|c|c|c|c|}
\hline$\#$ & $\begin{array}{c}\delta_{\text {iso }} \\
/ \mathbf{p p m} \\
( \pm 1)\end{array}$ & $\begin{array}{c}C_{\mathrm{Q}} \text { centre } \\
\text { /MHz } \\
( \pm 0.1)\end{array}$ & $\begin{array}{c}C_{Q} \text { width } \\
\text { /MHz } \\
( \pm 0.1)\end{array}$ & $\begin{array}{c}\eta \mathbf{Q} \\
( \pm 0.01)\end{array}$ & $\begin{array}{c}\text { broadening } \\
\text { /KHz } \\
( \pm 0.1)\end{array}$ & species & $\begin{array}{c}\text { integrated intensity } \\
\qquad 1 \%\end{array}$ & $\begin{array}{c}\text { species total intensity } \\
\qquad \%\end{array}$ \\
\hline \multirow[t]{6}{*}{ A1 } & 7 & 10.1 & 2.0 & 0.4 & 1.6 & $\mathrm{AlO}_{6}$ & & \multirow{2}{*}{$48 \pm 3$} \\
\hline & 11 & 5.6 & 4.5 & 1.0 & 0.9 & $\mathrm{AlO}_{6}$ & $14 \pm 2$ & \\
\hline & 34 & 4.9 & 3.3 & 1.0 & 0.7 & $\mathrm{AlO}_{5}$ & $15 \pm 1$ & \multirow{3}{*}{$42 \pm 3$} \\
\hline & 42 & 4.0 & 1.4 & 0.5 & 0.7 & $\mathrm{AlO}_{5}$ & $11 \pm 1$ & \\
\hline & 49 & 6.9 & 1.1 & 0.0 & 1.5 & $\mathrm{AlO}_{5}$ & $16 \pm 1$ & \\
\hline & 71 & 8.0 & 4.9 & 1.0 & 2.8 & $\mathrm{AlO}_{4}$ & $10 \pm 1$ & $10 \pm 1$ \\
\hline \multirow[t]{6}{*}{ A4 } & 6 & 10.1 & 2.0 & 0.4 & 1.6 & $\mathrm{AlO}_{6}$ & $36 \pm 1$ & \multirow{2}{*}{$47 \pm 3$} \\
\hline & 11 & 5.6 & 4.5 & 1.0 & 0.9 & $\mathrm{AlO}_{6}$ & $11 \pm 2$ & \\
\hline & 34 & 4.9 & 3.3 & 1.0 & 0.6 & $\mathrm{AlO}_{5}$ & $16 \pm 2$ & \multirow{3}{*}{$45 \pm 5$} \\
\hline & 42 & 4.0 & 1.4 & 0.5 & 0.8 & $\mathrm{AlO}_{5}$ & $16 \pm 1$ & \\
\hline & 49 & 7.1 & 0.8 & 0.0 & 1.0 & $\mathrm{AlO}_{5}$ & $13 \pm 3$ & \\
\hline & 77 & 8.0 & 4.9 & 1.0 & 2.8 & $\mathrm{AlO}_{4}$ & $9 \pm 2$ & $9 \pm 2$ \\
\hline
\end{tabular}

$\delta_{\text {iso }}=$ chemical shift, $C_{\mathrm{Q}}=$ quadrupole coupling constants, $\eta_{\mathrm{Q}}=$ asymmetry parameter 


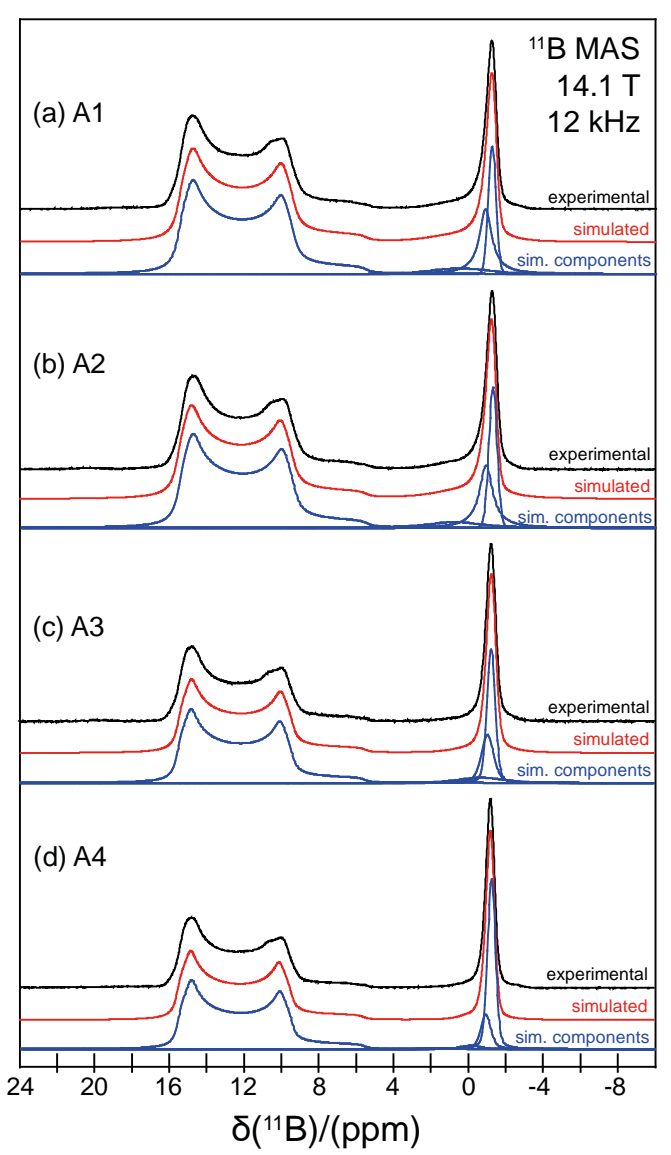

(a) A1

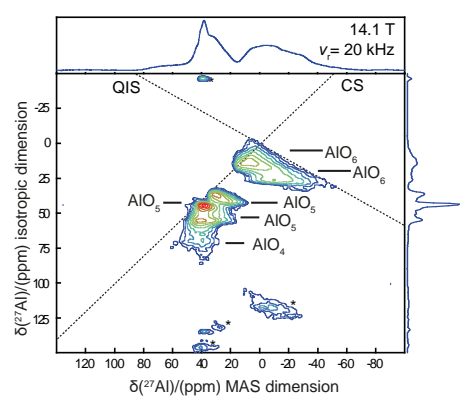

$\delta\left({ }^{(27} \mathrm{Al}\right) /(\mathrm{ppm}) \mathrm{MAS}$ dimension

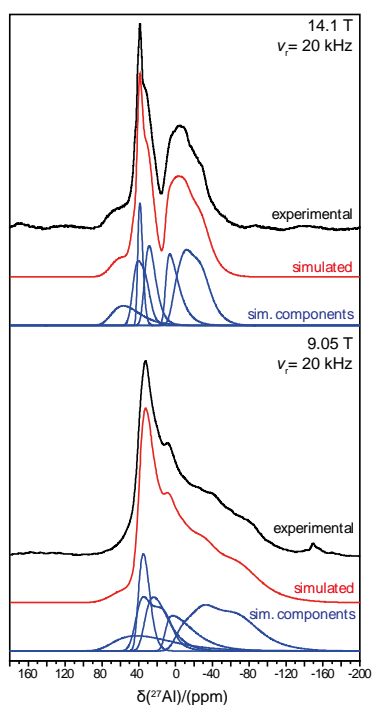

(b) A4
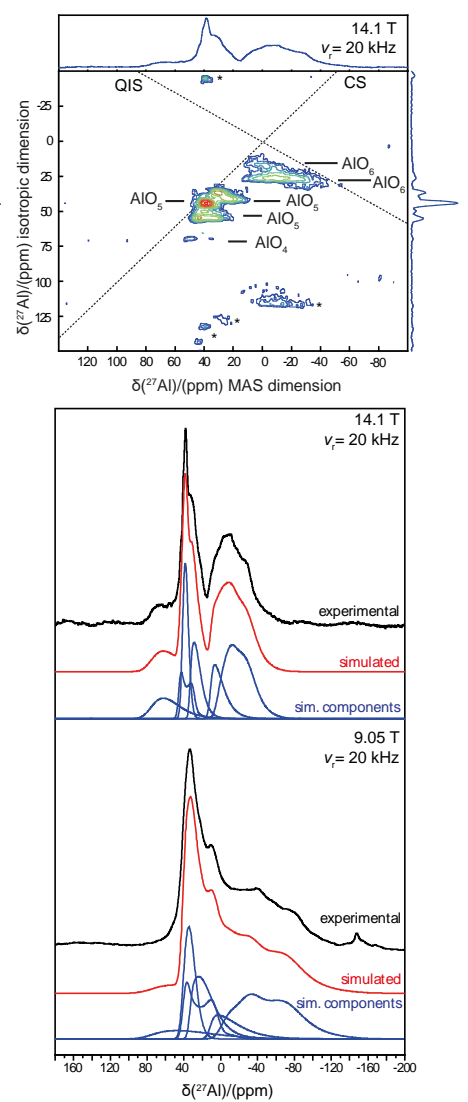

Figure 10. left: Experimental ${ }^{11} \mathrm{~B}$ MAS NMR spectra for $\mathrm{A}_{2} \mathrm{~B}$ series at $14.1 \mathrm{~T}$ (black lines) displayed with the simulations of the corresponding spectra (red lines) and the simulated components (blue lines); right: ${ }^{27} \mathrm{Al}$ MQMAS NMR data (top) and ${ }^{27} \mathrm{Al}$ MAS NMR spectra and deconvolutions at $14.1 \mathrm{~T}$ and $9.40 \mathrm{~T}$ (bottom) for selected samples with an initial $\mathrm{Al}$ content of (a) $70 \mathrm{wt} \% \mathrm{Al}_{2} \mathrm{O}_{3}$ and (b) $35 \mathrm{wt} \% \mathrm{Al}_{2} \mathrm{O}_{3}$.

As seen in the diffraction experiments the Al1 position is refined to be 5-fold coordinated, as well as the $\mathrm{Al} 3$ site in case of a fully occupied $\mathrm{O} 10$ site. Both are associated to $\mathrm{AlO}_{5}$ species in the NMR data. The third $\mathrm{AlO}_{5}$ species and the $\mathrm{AlO}_{4}$ species show a larger quadrupole interaction compared to the other non-octahedral sites (see Tab. 12). Therefore it is likely that they are associated to the Al2 and Al4 sites both refined to be 4-fold coordinated with an additional longer bond to the atoms $\mathrm{O} 8$ (A12) or O2 (A14). As they show a similar geometry, they may not be clearly distinguishable in the NMR. Two octahedrally coordinated sites are determined with a site occupancy of about $35 \%$ and $12 \%$, which agrees well with our previous studies [24]. Fischer et al. [24] assigned the more populated Al site to a combination of Al5 and Al7 as these two sites show a larger distortion index (DI) correlating with a larger 
quadrupole interaction in the NMR data. This is confirmed by the model obtained from the electron-diffraction experiment showing the distortion of the octahedra Al6 $(\mathrm{DI}(\mathrm{OMO})=0.039)$ to be slighly smaller than those of the octahedra Al5 and Al7, representing a distortion of $\mathrm{DI}(\mathrm{OMO})=0.054$ for the $\mathrm{Al} \mathrm{O}_{6}$ and of 0.066 for the $\mathrm{Al} 7 \mathrm{O}_{6}$ (the DI:(OMO) is calculated after [45]), correlating well with the quadrupole interaction in the NMR as shown in Table 12.

FTIR and Raman spectra are collected for all samples of the $\mathrm{A}_{2} \mathrm{~B}$ series. The spectra of one representative sample (A4) are shown in Figure 5, the corresponding spectra of the samples A1 - A3 look almost identical without significant changes. Broad absorption modes are observed at about $3400 \mathrm{~cm}^{-1}$ in the samples A1 and A2 which can be assigned to $\mathrm{OH}$ groups at the surface. A further discussion of the B-O and Al-O modes is given in chapter 3.1 (part spectroscopy).

\section{Density-functional theory calculations}

A comparison of the DFT energies reveals that the model in which O10 is fully occupied is energetically more favorable compared with the model with a $50 \%$ occupation of both O5 and $\mathrm{O} 10$, with a difference in total energy of $42 \mathrm{~kJ} / \mathrm{mol}$ (per $\mathrm{Al}_{4} \mathrm{~B}_{2} \mathrm{O}_{9}$ formula unit). In the structure without $\mathrm{O} 5$ atoms the atoms B3 and Al1 remain close to their initial positions in the DFT optimization. In contrast, the presence of O5 in the channels leads to a shift of these atoms towards the channel interior leading to a change in coordination to a tetrahedral environment. Therefore, the amount of tetrahedrally coordinated boron/aluminum would be increased at the expense of trigonally coordinated boron and fivefold-coordinated aluminum if O5 is occupied. 


\section{Conclusions}

The Al-rich aluminum borate compounds were synthesized using two different synthesis routes and different initial Al/B ratios. All samples show the aluminum borate phase together with different amounts of impurity phase $\left(\mathrm{Al}_{2} \mathrm{O}_{3}\right.$ or $\left.\mathrm{A}_{2} \mathrm{~B}\right)$ if present. Chemical analysis clearly shows a trend in the $\mathrm{Al} / \mathrm{B}$ ratio instead of a fixed chemical composition, thus, indicating the solid solution occurs within a narrow limit. Based on the results of PGAA and NMR spectroscopy, the substitution of $\mathrm{Al}$ by $\mathrm{B}$ is assumed to be in the range of about $1-3 \%$. This is supported by the powder diffraction data, confirming $3.3(6) \%$ vacancies on the Al2 site. The NMR data show a small amount of boron to be present in fourfold coordination; this content of $\mathrm{BO}_{4}$ is below the detection limit of the IR spectra. A correlation of $\mathrm{BO}_{4}$ and a second $\mathrm{AlO}_{6}$ site is observed in the $\mathrm{NMR}$ data. Therefore, it might be likely that $\mathrm{BO}_{4}$ units are located in the surrounding of $\mathrm{AlO}_{6}$ octahedra. This would induce a distortion of the octahedra, what in turn might be assigned to the additional $\mathrm{AlO}_{6}$ site as observed in the ${ }^{27} \mathrm{Al}$ MAS NMR data. Such distortion of the octahedra caused by small $\mathrm{BO}_{\mathrm{x}}$ units was also observed for the $\mathrm{Al}_{6-\mathrm{x}} \mathrm{B}_{\mathrm{x}} \mathrm{O}_{9}$ phases [9]. However, a new boron position cannot be found, as this is certainly prevented by the small amount of substitution. Disorder effects are assumed for samples synthesized from sol-gel precursors with a high amount of initial alumina, confirmed by the

${ }^{27} \mathrm{Al}$ NMR data, representing a significant difference in the $\mathrm{AlO}_{4} / \mathrm{AlO}_{5}$ ratio for these samples. Thermal analysis indicates an incongruent melting for the Al-rich aluminum borate phase. Decomposition is observed to start between 1473-1673 K. Continuing thermal treatment at $1673 \mathrm{~K}$ leads to a complete decomposition.

The crystal structure of $\mathrm{Al}_{4} \mathrm{~B}_{2} \mathrm{O}_{9}$ was re-investigated. It was shown by electron diffraction that structural details vary among different crystals and even inside a crystallite. Predominant are domains with an ordered distribution of atoms, clearly showing that there is no significant signal for the second postulated oxygen O5 in the channel, and other domains with a probable disordered configuration of $\mathrm{O} 5$ and $\mathrm{O} 10$ as indicated by diffuse scattering. This explains that 
the X-ray and neutron diffraction experiments yielded disordered oxygen positions representing an average structure over all unit cells and domains. A comparison of the DFT energies reveals that the model in which $\mathrm{O} 10$ is fully occupied is energetically more favored over the model with a $50 \%$ occupation of both $\mathrm{O} 5$ and O10. The ${ }^{11} \mathrm{~B}$ NMR data show about $1 / 4$ of the boron atoms to be tetrahedrally coordinated, thus correlating well with a fully occupied $\mathrm{O} 10$ position. A trend of a slightly increasing $\mathrm{BO}_{4}$ content is observed for increasing initial boron content.

\section{Acknowledgements}

We gratefully thank the Deutsche Forschungsgemeinschaft (DFG) for the financial support of the projects GE1981/5-1 and FI442/19-1, as well as the financial support provided by FRM II to perform neutron scattering experiments at the Forschungsneutronenquelle Heinz MaierLeibnitz Zentrum (MLZ), Garching, Germany. HZ and UK thank the Carl-Zeiss Stiftung Germany for financial support. TMG thanks the DFG for support in the Heisenberg program GE1981/3-1 and GE1981/3-2. JVH thanks the EPSRC, the University of Warwick and the Birmingham Science City Program for partial funding of the solid state NMR infrastructure at Warwick. The latter program accessed the Birmingham Science City Advanced Materials Project 1: Creating and Characterizing Next Generation Advanced Materials, which derived support from Advantage West Midlands (AWM) and the European Regional Development Fund (ERDF). This work is based upon experiments performed at the SPODI instrument operated by A. Senyshyn, and experiments performed at the PGAA instrument operated by P. Kudějová at the Heinz Maier-Leibnitz Zentrum (MLZ), Garching, Germany. The authors thank the Institut Laue-Langevin, Grenoble, France, for the allocation of neutron beam time. MFI would like to thank Prof Dr Andreas Lüttge and Dr Rolf Arvidson (Marum, Bremen) for generous access to the Asgard cluster, and the Central Research Development Fund (CRDF) of the University of Bremen for funding (Funding line 04 - Independent Projects for PostDocs). We gratefully thank the Shikoku Chemical Corporation (Japan) for providing the Alborite and Alborex samples. 


\section{References}

[1] R.X. Fischer, H. Schneider, in: H. Schneider, S. Komarneni, (Eds.), Mullite, Wiley VCH, Weinheim, 2005, pp. 1-46, 128-140.

[2] R.X. Fischer, H. Schneider, European Journal of Mineralogy 20 (2008) 917-933.

[3] J. Zhang, J. Lin, H.S. Song, E.M. Elssfah, S.J. Liu, J.J. Luo, X.X. Ding, C. Tang, S.R. Qi, Materials Letters 60 (2006) 3292-3295.

[4] C.C. Tang, E.M. Elssfah, J. Zhang, D.F. Chen, Nanotechnology 17 (2006) 2362-2367.

[5] L.M. Peng, X.K. Li, H. Li, J.H. Wang, M. Gong, Ceramics International 32 (2006) $365-368$.

[6] X. Tao, X. Wang, X. Li, Nano letters 7 (2007) 3172-3176.

[7] P.J.M. Gielisse, W.R. Foster, Nature 195 (1962) 69-70.

[8] D. Mazza, M. Vallino, G. Busca, Journal of the American Ceramic Society 75 (1992) 1929-1934.

[9] K. Hoffmann, T.J.N. Hooper, M.M. Murshed, O. Dolotko, Z. Révay, A. Senyshyn, H. Schneider, J.V. Hanna, T.M. Gesing, R.X. Fischer, Journal of Solid State Chemistry 243 (2016) 124-135.

[10] M. Garsche, E. Tillmanns, H. Almen, H. Schneider, V. Kupcik, European Journal of Mineralogy 3 (1991) 793-808.

[11] Y.V. Sokolova, A.V. Azizov, M.A. Simonov, N.I. Leonyuk, N.V. Belov, Doklady Akademii Nauk SSSR 243 (1978) 655-658 (in Russian).

[12] M. Ihara, K. Imai, J. Fukunaga, N. Yoshida, Yogyo Kyokai Shi 88 (1980) 77-84.

[13] G.D. Gatta, N. Rotiroti, M. Fisch, T. Armbruster, Physics and Chemistry of Minerals 37 (2010) 227-236. 
[14] G.D. Gatta, P. Lotti, M. Merlini, H.-P. Liermann, M. Fisch, Journal of the American Ceramic Society 96 (2013) 2583-2592.

[15] M. Fisch, T. Armbruster, D. Rentsch, E. Libowitzky, T. Pettke, Journal of Solid State Chemistry 184 (2011) 70-80.

[16] T.M. Gesing, C. Mendive, M. Curti, D. Hansmann, G. Nénert, P. Kalita, K. Lipinska, A. Huq, A. Cornelius, M. Murshed, Zeitschrift für Kristallographie-Crystalline Materials 228 (2013) 532-543.

[17] M.M. Murshed, A. Rusen, R.X. Fischer, T.M. Gesing, Materials Research Bulletin 47 (2012) 1323-1330.

[18] M.M. Murshed, R.X. Fischer, T.M. Gesing, Zeitschrift für KristallographieCrystalline Materials 227 (2012) 580-584.

[19] M.M. Murshed, G. Nénert, T.M. Gesing, Zeitschrift für Kristallographie-New Crystal Structures 227 (2012) 285-286.

[20] H.N. Baumann, C.H. Moore, Journal of the American Ceramic Society 25 (1942) 391-394.

[21] H. Scholze, Zeitschrift für anorganische und allgemeine Chemie 284 (1956) 272-277 (in German).

[22] T. Rymon-Lipinski, H.W. Hennicke, W. Lingenberg, Keramische Zeitschrift 37 (1985) 450-453.

[23] S.C. Corporation, Shikoku Chemical Corporation, Certificate of Analysis (Alborite PF03 and Alborex Y) 2008.

[24] R.X. Fischer, V. Kahlenberg, D. Voll, K.J.D. MacKenzie, M.E. Smith, B. Schnetger, H.-J. Brumsack, H. Schneider, American Mineralogist 93 (2008) 918-927.

[25] K. Hoffmann, M.M. Murshed, R.X. Fischer, H. Schneider, T.M. Gesing, Zeitschrift für Kristallographie - Crystalline Materials 229 (2014) 699-708. 
[26] T.M. Gesing, R.X. Fischer, M. Burianek, M. Mühlberg, T. Debnath, C.H. Rüscher, J. Ottinger, J.-C. Buhl, H. Schneider, Journal of the European Ceramic Society 31 (2011) 30553062.

[27] K.J. Griesser, A. Beran, D. Voll, H. Schneider, Mineralogy and Petrology 92 (2008) 309-320.

[28] M. Hoelzel, A. Senyshyn, O. Dolotko, Journal of large-scale research facilities JLSRF 1 (2015) A5.

[29] J. Birkenstock, R.X. Fischer, T. Messner, Zeitschrift für Kristallographie, Supplementary 23 (2006) 237-242.

[30] U. Kolb, T. Gorelik, C. Kübel, M. Otten, D. Hubert, Ultramicroscopy 107 (2007) 507-513.

[31] E. Lippmaa, A. Samoson, M. Mägi, Journal of the American Chemical Society 108 (1986) 1730-1735.

[32] M. Rowles, J.V. Hanna, K. Pike, M.E. Smith, B. O'Connor, Applied Magnetic Resonance 32 (2007) 663-689.

[33] D. Massiot, F. Fayon, M. Capron, I. King, S. Le Calvé, B. Alonso, J.O. Durand, B. Bujoli, Z. Gan, G. Hoatson, Magnetic Resonance in Chemistry 40 (2002) 70-76.

[34] S.J. Clark, M.D. Segall, C.J. Pickard, P.J. Hasnip, M.I. Probert, K. Refson, M.C. Payne, Zeitschrift für Kristallographie - Crystalline Materials 220 (2005) 567-570.

[35] J.P. Perdew, A. Ruzsinszky, G.I. Csonka, O.A. Vydrov, G.E. Scuseria, L.A. Constantin, X. Zhou, K. Burke, Physical Review Letters 100 (2008) 136406.

[36] NETZSCH, NETZSCH Gerätebau GmbH, Selb / Bayern, 2010.

[37] S. Söllradl, H. Lührs, Z. Révay, P. Kudějová, L. Canella, A. Türler, Journal of Radioanalytical and Nuclear Chemistry 298 (2013) 2069-2073. 
[38] Z. Révay, P. Kudějová, K. Kleszcz, S. Söllradl, C. Genreith, Nuclear Instruments and Methods in Physics Research Section A: Accelerators, Spectrometers, Detectors and Associated Equipment 799 (2015) 114-123.

[39] Z. Révay, Journal of large-scale research facilities JLSRF 1 (2015) A20.

[40] N. Ishizawa, T. Miyata, I. Minato, F. Marumo, S.I. Iwai, Acta Crystallographica Section B: Structural Crystallography and Crystal Chemistry 36 (1980) 228-230.

[41] U. Kolb, E. Mugnaioli, T. Gorelik, Crystal Research and Technology 46 (2011) 542554.

[42] D.R. Peacor, R.C. Rouse, E.S. Grew, American Mineralogist 84 (1999) 1152-1161.

[43] H. Zhao, Y. Krysiak, K. Hoffmann, B. Barton, L. Molina-Luna, R. Neder, H.-J. Kleebe, T.M. Gesing, H. Schneider, R.X. Fischer, U. Kolb, in preparation.

[44] T.F. Kemp, M.E. Smith, Solid state nuclear magnetic resonance 35 (2009) 243-252.

[45] W. Baur, Acta Crystallographica Section B: Structural Crystallography and Crystal Chemistry 30 (1974) 1195-1215.

Highlights:

The crystal structure of $\mathrm{Al}_{4} \mathrm{~B}_{2} \mathrm{O}_{9}$ was re-evaluated.

Structural details vary among different crystals and inside $\mathrm{Al}_{4} \mathrm{~B}_{2} \mathrm{O}_{9}$ crystallites.

Diffuse scattering indicate a probable disordered configuration of O5 and O10.

A solid solution series for $\mathrm{Al}_{5-\mathrm{x}} \mathrm{B}_{\mathrm{x}} \mathrm{O}_{9}$ is indicated by PGAA and NMR spectroscopy.

The presence of $\mathrm{BO}_{4}$ groups is confirmed by ${ }^{11} \mathrm{~B}$ MAS NMR spectroscopy for $\mathrm{Al}_{5-\mathrm{x}} \mathrm{B}_{1+\mathrm{x}} \mathrm{O}_{9}$. 